\title{
Debunking Intellectual Property Myths: Cross-Cultural Experiments on Perceptions of Property
}

\author{
Gregory N. Mandel, ${ }^{*}$ Kristina R. Olson, ${ }^{* *} \mathcal{E}$ Anne A. Fast ${ }^{* * *}$
}

For decades, the prevailing view in the United States and many Western countries has been that China does not appropriately respect intellectual property rights. These beliefs lie at the heart of President Donald Trump's current trade war with China. Despite substantial geopolitical debate over differences between American and Chinese attitudes towards intellectual property rights, and despite the critical effects that such attitudes have on international economic markets and the function of intellectual property systems, empirical evidence of these attitudes is largely lacking. This Article presents original experimental survey research that explores cross-cultural differences between American and Chinese attitudes towards intellectual property rights, personal property rights, and real property rights.

The results of the studies are somewhat counterintuitive. First, Chinese participants are found to have more consistent preferences towards different types of property rights than Americans. In a series of vignettes designed to test attitudes towards patented subject matter, copyrighted subject matter, tangible personal property, and real property, Chinese responses were more consistent and less context driven. Second, Americans do identify a preference for stronger intellectual property rights than Chinese, but only where infringement is committed by a private party for private benefit. Where infringement is conducted for public benefit, whether by a private or a governmental entity,

*Dean and Peter J. Liacouras Professor of Law, Temple University. We are deeply grateful to Associate Professor Ma Biyu, Yunnan University Law School, for her assistance in carrying out our research. We also thank Madhumita Anand, Diana Joskowicz, and Christine Shu for their outstanding research assistance on this project. This research is based upon work supported by the National Science Foundation under Grant No. 1324138 and 1322514.

**Associate Professor of Psychology, University of Washington.

***Assistant Professor of Psychology, Western Washington University. 
Chinese and Americans tend to have the same attitudes towards intellectual property rights. Third, Americans display a lower regard for intellectual property rights than for tangible property rights in most contexts, a differential that is not echoed in Chinese responses. The distinctions that Americans draw based on the use to which property is put, and between intellectual property and tangible property, is not consistent with United States law.

Our experiments reveal that the ongoing debates over Chinese attitudes towards intellectual property rights miss the mark in certain regards. Chinese and American preferences for property rights are more similar than most have assumed, and the manners in which they differ are inconsistent with most proffered theories. These results provide important lessons for the future of international intellectual property rights relations, discourse, and enforcement.

\section{CONTENTS}

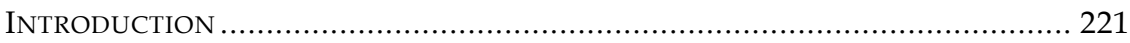

I. Culture, Property, And Intellectual Property .................................. 227

A. Intellectual Property Rights Across Cultures ....................................228

1. Intellectual property development in China..............................229

2. Intellectual property development in the United States ...........236

B. Personal Property and Real Property Across Cultures ....................2239

C. Psychological Conceptions of Property ..............................................241

II. Experiments on Cross-Cultural Perceptions of Property Rights ..... 243

A. Study 1: Cross-Cultural Study of American College Students ........243

1. Study 1 methodology ...............................................................24

2. Study 1 results .......................................................................248

B. Study 2: Cross-Cultural Study of American and Chinese

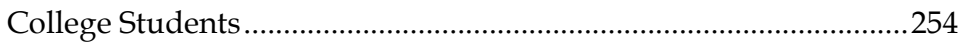

1. Study 2 methodology ...............................................................254

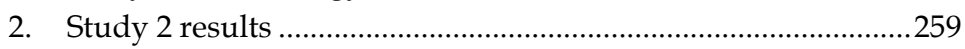

III. Reconceptualizing Culture, Property, ANd Intellectual

PROPERTY EXCEPTIONALISM.................................................... 263

A. American Preferences for Stronger Property Rights

Are Contextual......................................................................................263

B. Chinese Consistency, American Variation...........................................265

C. Chinese Intellectual Property Exceptionalism, or American? .........266 
D. Purpose Matters..................................................................................267

E. Preferencing Personal Property ..........................................................2269

F. The Psychology of Property Rights................................................22

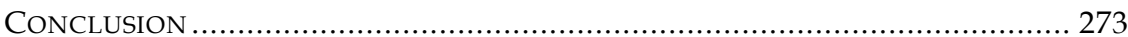

\section{INTRODUCTION}

For decades, the prevailing view among Western governments, industries, and experts has been that the Chinese government and populace have a widespread disregard for intellectual property rights. ${ }^{1}$ This assessment has led to significant trade, political, and economic disputes. ${ }^{2}$ China has enacted a series of stronger, more Westernized intellectual property laws during this period. ${ }^{3}$ Although China's approach to intellectual property is strengthening, many in the United States and other Western countries still believe that, despite China's tougher intellectual property laws, it is not doing enough to enforce these rights and that infringement runs rampant. ${ }^{4}$ Such beliefs are the primary

1. Andrew C. Mertha, The Politics of Piracy: Intellectual Property in CONTEMPORARY CHINA 167 (2005); Robert C. Bird, Defending Intellectual Property Rights in the BRIC Economies, 43 AM. BUS. L.J. 317, 333 (2006) ("The sheer volume of copyright and trademark piracy in China is staggering."); Xuan-Thao Nguyen, The China We Hardly Know: Revealing the New China's Intellectual Property Regime, 55 ST. LOUIS U. L.J. 773, 773 (2011) ("The long-held and virtually unquestioned view about China from the United States and other Western nations is that China has a total disregard for intellectual property rights."); Shruti Rana, The Global Battle over Copyright Reform: Developing the Rule of Law in the Chinese Business Context, 53 STAN. J. INT'L L. 89, 92 (2017) (“[B]usinesses and governments around the world have repeatedly singled out Chinese companies as among the world's most notorious copyright pirates.").

2. Bird, supra note 1, at 329; Julia Cheng, China's Copyright System: Rising to the Spirit of TRIPS Requires an Internal Focus and WTO Membership, 21 FORDHAM INT'L L.J. 1941, 1943 (1998); Rana, supra note 1, at 91; Wei Shi \& Robert Weatherley, Harmony or Coercion? China-EU Trade Dispute Involving Intellectual Property Enforcement, 25 WIS. INT'L L.J. 439, 442-43 (2007).

3. Bird, supra note 1, at 334; Scott J. Palmer, An Identity Crisis: Regime Legitimacy and the Politics of Intellectual Property Rights in China, 8 IND. J. GLOB. LEGAL STUD. 449, 450 (2001); Rana, supra note 1 , at $91-92$.

4. Donald P. Harris, The Honeymoon Is Over: The U.S.-China WTO Intellectual Property Complaint, 32 FORDHAM INT'L L.J. 96, 105 (2008); Rana, supra note 1, at 126 (noting that while China has made significant efforts, some believe that such efforts and enforcement are lacking); Anne M. Wall, Intellectual Property Protection in China: Enforcing Trademark Rights, 17 MARQ. SPORTS L. REV. 341, 416 (2006); William Weightman, China's Progress on Intellectual Property Rights (Yes, Really), THE DiPLOMAT (Jan. 20, 2018), https://thediplomat.com/ 2018/01/chinas-progress-on-intellectual-property-rights-yes-really/ ("China has become 


\section{driver of the current trade war between the United States and China. ${ }^{5}$}

A number of experts have argued that the challenges of intellectual property enforcement in China are unsurprising because efforts to introduce Western notions of intellectual property rights into China largely have ignored the differences between Chinese and Western values, cultures, and institutions. ${ }^{6}$ Rather, Western nations have attempted to compel China to ramp up intellectual property protection through diplomatic and financial pressure. ${ }^{7}$ This goal, for example, is an explicit objective of

increasingly innovative and has demonstrated a serious resolve to enforce an effective IPR regime.").

5. Statement from President Donald J. Trump on Additional Proposed Section 301 Remedies, WHITE HOUSE (Apr. 5, 2018), https://www.whitehouse.gov/briefings-statements/ statement-president-donald-j-trump-additional-proposed-section-301-remedies/ ("Following a thorough investigation under section 301 of the Trade Act of 1974, the United States Trade Representative (USTR) determined that China has repeatedly engaged in practices to unfairly obtain America's intellectual property. ... China's illicit trade practices - ignored for years by Washington - have destroyed thousands of American factories and millions of American jobs."); Statement by the President Regarding Trade with China, WHITE HOUSE (June 15, 2018) [hereinafter Statement by the President Regarding Trade with China (June 15, 2018)], https://www.whitehouse.gov/briefings-statements/statement-presidentregarding-trade-china/ ("China has, for example, long been engaging in several unfair practices related to the acquisition of American intellectual property and technology."); U.S. Delegation, Section 2: Protection of American Technology and Intellectual Property,

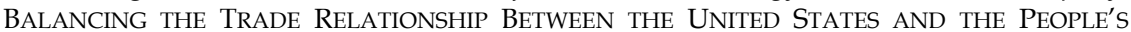
REPUBLIC OF CHINA, https://xqdoc.imedao.com/16329fa0c8b2da913fc9058b.pdf (providing a variety of intellectual property demands among the United States' list of demands before talks in Beijing to try to resolve the trade dispute); see Bryce Baschuk, U.S. Takes Aim at China in WTO, Escalating Stakes of Trade War, BLOOMBERG LAW (Oct. 19, 2018), https://www.bloomberglaw.com/document/X640AKN0000000?bna_news_filter=iplaw\&jcsearch=BNA\%2520000001668c0ed347ad778fdee8250000\#jcite (discussing the United States WTO complaint against Chinese intellectual property rights practices).

6. William P. ALFORD, TO STEAL a BOOK Is AN Elegant OfFENSE: InTELleCtuAL PROPERTy LAW IN CHINESE CiVILIZATION 2 (1995); see Jennifer A. Crane, Riding the Tiger: A Comparison of Intellectual Property Rights in the United States and the People's Republic of China, 7 CHI.-Kent J. InTEll. Prop. 95 (2008) (reaching the same conclusion); Peter K. Yu, From Pirates to Partners: Protecting Intellectual Property in China in the Twenty-First Century, 50 AM. U. L. REV. 131 (2000) (also reaching the same conclusion).

7. ALFORD, supra note 6, at 1; Bird, supra note 1, at 334 ("Threats of a trade war encouraged China to enact more stringent copyright laws and close pirating factories."); Patricia E. Campbell \& Michael Pecht, The Emperor's New Clothes: Intellectual Property Protections in China, 7 J. Bus. \& TECH. L. 69, 72-75 (2012); Jacques deLisle, Lex Americana: United States Legal Assistance, American Legal Models, and Legal Change in the Post-Communist World and Beyond, 20 U. PA. J. INT'L ECON. L. 179, 211, 222 (1999) (“The United States relied on pressure, more than assistance, in its quest to influence the shape of China's intellectual property law."); Gregory N. Mandel, Leveraging the International Economy of 
President Donald Trump's increased tariffs on Chinese goods. ${ }^{8}$ Trying to implement intellectual property via pressure, however, will not incorporate its concepts into the culture and consciousness of Chinese people. ${ }^{9}$ As a consequence of this approach, there is a disconnect between China's reasons for implementing intellectual property laws and the evolution of popular attitudes towards the laws.

Despite the long-running debates over intellectual property protection and about differing American versus Chinese attitudes towards intellectual property rights, no one has ever tested these underlying hypotheses. This is striking, particularly given the current trade disputes and that America and China lead the world in granting intellectual property rights. ${ }^{10}$ There are data that

Intellectual Property, 75 OHIO ST. L.J. 733, 738-39 (2014) (discussing the diplomatic and financial pressures); Shi \& Weatherley, supra note 2, at 445 ("Since the beginning of the 1990s, in order to achieve instant improvement of IPR enforcement, the United States has frequently leveraged a series of unilateral mechanisms - trade wars, non-renewal of Most Favored Nation (MFN) status, and opposition to entry into the WTO - to push China towards stronger protection of the U.S. IPR.").

8. Presidential Memorandum, Actions by the United States Related to the Section 301 Investigation of China's Laws, Policies, Practices, or Actions Related to Technology Transfer, Intellectual Property, and Innovation, 83 Fed. Reg. 13099 (Mar. 22, 2018) (discussing the actions the United States will take in response to the Trade Representative's findings that China is harming American intellectual property); Statement from President Donald J. Trump on Additional Proposed Section 301 Remedies, supra note 5 ("On April 3, 2018, the USTR announced approximately $\$ 50$ billion in proposed tariffs on imports from China as an initial means to obtain the elimination of policies and practices identified in the investigation.... [T] he United States is still prepared to have discussions in further support of our commitment to achieving free, fair, and reciprocal trade and to protect the technology and intellectual property of American companies and American people."); Statement by the President Regarding Trade with China (June 15, 2018), supra note 5 ("These tariffs are essential to preventing further unfair transfers of American technology and intellectual property to China, which will protect American jobs."); Statement from the President Regarding Trade with China, WHITE HOUSE (June 18, 2018), https://www.whitehouse.gov/briefingsstatements/statement-president-regarding-trade-china-2/ ("China apparently has no intention of changing its unfair practices related to the acquisition of American intellectual property and technology. Rather than altering those practices, it is now threatening United States companies, workers, and farmers who have done nothing wrong.").

9. AlFORD, supra note 6, at 54; Crane, supra note 6; Peter K. Yu, Piracy, Prejudice, and Perspectives: An Attempt to Use Shakespeare to Reconfigure the U.S.-China Intellectual Property Debate, 19 B.U. INT'L L.J. 1, 3, 16 (2001); see also Anupam Chander \& Madhavi Sunder, The Battle to Define Asia's Intellectual Property Law: From TPP to RCEP, 8 U.C. IRVINE L. REV. 331 (2018) (discussing current debates over intellectual property treaties among various Asian countries including China and treaties with respect to the United States).

10. See, e.g., Who Filed the Most PCT Patent Applications in 2018?, WORLD INTELL. Prop. ORG., http://www.wipo.int/export/sites/www/ipstats/en/docs/infographic_pct_201 8.pdf (last visited Mar. 15, 2020) (identifying the United States and China as first and second, 
indicate higher intellectual property infringement rates in China than in the United States. ${ }^{11}$ It is not feasible, however, to extrapolate from these data to reach conclusions about actual American and Chinese attitudes. A differential in infringement rates could result from different attitudes towards intellectual property rights, but it could also result from different efforts or means of enforcement, different economic pressures, or other factors.

Social and cultural psychologists have studied the cultural differences between Americans and Chinese in a variety of other contexts. ${ }^{12}$ Such research has found that East Asians tend to have a more collectivistic and interdependent view of the self, while Westerners tend to have a more individualistic and independent view. ${ }^{13}$ These results are consistent with some of the arguments about the effects of Chinese and American cultures on attitudes towards intellectual property rights, but none of the studies have examined attitudes towards intellectual or other property rights. The present study is designed to begin to remedy this gap.

We recruited American college students at a large American university and Chinese college students at a large Chinese

respectively, in Patent Cooperation Treaty application filings by country in 2018); Who Filed the Most Madrid Trademark Applications in 2018?, WORLD INTELL. PROP. ORG., http://www.wipo.int/export/sites/www/ipstats/en/docs/infographic_madrid_2018.pdf (last visited Mar. 15, 2020) (identifying the United States, Germany, and China as first through third, respectively, in Madrid Agreement trademark application filings by country in 2018).

11. See, e.g., Matt Rosoff, The Countries Where People Steal the Most Data, BUS. INSIDER (July 7, 2016), http://www.businessinsider.sg/software-piracy-rates-and-value-bycountry-2016-7/?r=US\&IR=T ("Software piracy is a lot more rampant in China than the U.S., but the value of unlicensed software in the U.S. is still the highest in the world.").

12. Guo-Ming Chen, Differences in Self-Disclosure Patterns Among Americans Versus Chinese: A Comparative Study, 26 J. Cross-Cultural PsyCH. 84, 84-91 (1995); Rosina C. Chia, Jamie L. Moore, Ka Nei Lam, C.J. Chuang \& B.S. Cheng, Cultural Differences in Gender Role Attitudes Between Chinese and American Students, 31 SEX ROLES 23, 23-30 (1994); Li-Jun Ji, Kaiping Peng \& Richard E. Nisbett, Culture, Control, and Perception of Relationships in the Environment, 78 J. PeRSONALITY \& SOC. PsYCH. 943, 943-55 (2000); Michael W. Morris \& Kaiping Peng, Culture and Cause: American and Chinese Attributions for Social and Physical Events, 67 J. Personality \& SOC. PsyCH. 949, 949-71 (1994); Deborah Stipek, Differences Between Americans and Chinese in the Circumstances Evoking Pride, Shame, and Guilt, 29 J. CRossCUltural PSYCH. 616, 616-29 (1998).

13. Hazel Rose Markus \& Shinobu Kitayama, Culture and Self: Implications for Cognition, Emotion, and Motivation, 98 PsYCH. REV. 223, 223-53 (1991); Daphna Oyserman \& Spike Wing-Sing Lee, Priming "Culture": Culture as Situated Cognition, in HANDBOOK OF Cultural PsyCHOlOgY 255, 255-79 (Shinobu Kitayama \& Dov Cohen eds., 2007); Harry C. Triandis, Individualism-Collectivism and Personality, 69 J. PeRSONALITY 907, 907-24 (2001). 
university to take part in a series of survey experiments designed to test attitudes towards intellectual property, personal property, and real property rights. These studies do not test whether the United States' or China's property laws are apt, or whether their levels of enforcement are sufficient. Rather, the studies explore popular American and Chinese beliefs about the appropriateness of various types of property rights protection.

The results were somewhat surprising. When queried about support for personal, real, and intellectual property rights in general, Americans and Chinese supported property rights in each category at about the same level. When queried about specific scenarios involving property rights, however, Americans tended to prefer stronger property rights than Chinese. That said, the American responses were highly context dependent and, in some situations, American and Chinese responses were not statistically different.

The specific scenarios we tested included a variety of types of property (patent, copyright, personal, and real) and a variety of types of taking of property rights (a private party taking for a private purpose, a private party taking for a public purpose, and a public entity taking for a public purpose). Chinese responses to these differing circumstances were substantially more consistent than Americans across the twelve scenarios (four property domains by three taking types). Regardless of the type of property at issue, the entity taking the property, and the use to which the property was being put, Chinese participants gave relatively similar answers about their preferences for property rights. American responses, on the other hand, varied significantly.

The divisions that Americans drew concerning property rights were largely inconsistent with actual property law in the United States. For example, American participants drew a sharp distinction depending on the use to which property was being put. Americans were strongly opposed to property being taken for a private purpose (by a private party). They were close to equipoise, however, when property was taken for a public goal, regardless of whether a private or public party took the property. This distinction between a private party taking property for a private purpose versus for a public purpose is not supported in the law.

Intriguingly, Americans (and Chinese) also concluded that personal property should be protected to a greater extent than 
patents, copyrights, or land. This preference for personal property rights existed whether the land rights infringed involved merely trespass or the full taking of real property. This distinction also is not consistent with the law.

The results reported here shed some light on long-running debates over the purpose of property law. The American responses, favoring the use to which property is put over the rights of the user, indicate that public preferences are more consistent with a utilitarian, rather than deontological, view of private property rights. The strong protection of personal property rights also provides some support for personhood-based theories of property law.

Taken as a whole, these studies also indicate that those on all sides of the debates over Chinese attitudes towards intellectual property law have been making erroneous assumptions. Chinese attitudes towards intellectual property track Chinese attitudes towards tangible property relatively closely. It is not the case that Chinese tend to think of intellectual property exceptionally, but that they appear to have different attitudes towards property rights in general than Americans, a difference that is hardly surprising given China's different history and culture.

Further, Chinese attitudes towards intellectual property rights bear significant resemblance to American attitudes in certain regards-greater resemblance than many would likely predict. For example, in both the copyright and patent protection scenarios, Americans and Chinese had statistically similar responses for both private and public takings so long as they are for public purposes. The Chinese and American responses differed more in the personal and real property scenarios than in the intellectual property vignettes. These results have significant implications for the future of international intellectual property rights enforcement and discourse.

This Article is presented in three parts. Part I describes the differing histories of intellectual, personal, and real property rights in China and the United States. This Part also surveys prior psychological research on cultural differences between Americans and Chinese. We present our study design, methodology, and results in Part II. Part III discusses the implications of our survey experiments with respect to American and Chinese attitudes 
towards property rights in general and international intellectual property debates in particular.

\section{CUlTURE, PROPERTY, AND INTELLECTUAL PROPERTY}

In 1995, William Alford published his seminal work on intellectual property law and culture, To Steal a Book is an Elegant Offense: Intellectual Property Law in Chinese Civilization (hereinafter To Steal a Book). ${ }^{14}$ In this volume, Alford attacked the received wisdom of both Chinese and Western scholars that imperial China (221 BC-AD 1911) had developed an indigenous type of intellectual property rights. $^{15}$ Rather, Alford argued, scholars had misconstrued governmental control as intellectual property law, and in fact Chinese social and political culture created an environment that was largely antithetical to the notion of private intellectual property rights. ${ }^{16}$ To Steal a Book received significant acclaim and has become one of the most heavily cited intellectual property books of all time. ${ }^{17}$ While many concurred and were convinced by Alford's argument, ${ }^{18}$ others criticized it as not fully representative or a misunderstanding of Chinese culture. ${ }^{19}$

14. AlFORD, supra note 6.

15. Id. at 2 (citing Chengsi ZHENG \& MiChael PENDLETON, Copyright LAW IN CHINA (CCH International 1991)); Richard Adelstein \& Steven Peretz, The Competition of Technologies and Market for Ideas: Copyright and Fair Use-An Evolutionary Perspective, 5 INT'L REV. L. \& ECON. 209 (1985); Zou Shencheng, Baohu Banquan Shi Yu He Shi Heguo (The Protection of Copyright Started When and in What Country?), 63 FAXUE YANJIU (RSCH. LEGAL STUD.) 63 (1984).

16. ALFORD, supra note 6 , at 119.

17. A LexisNexis search for the title, for example, returns over 250 citation results.

18. E.g., David Briglia, To Steal a Book Is an Elegant Offense: Intellectual Property Law in Chinese Civilization by William P. Alford, 19 MD. J. INT'L L. \& TRADE 343, 347 (1995) ("William Alford offers a concise, remarkably readable, and illuminative account of the cultural history behind China's vexing intractability."); Thomas Buoye, William P. Alford, To Steal a Book Is an Elegant Offense: Intellectual Property Law in Chinese Civilization, 40 AM. J. LEGAL Hist. 514 (1996) ("If Alford is correct, and I believe he is ...."); Charles R. Stone, What Plagiarism Was Not: Some Preliminary Observations on Classical Chinese Attitudes Toward What the West Calls Intellectual Property, 92 MARQ. L. REV. 199, 207-09 (2008) (concluding that "Alford's book accurately explains" that Chinese authors rarely thought of copying from other works as stealing, even when copying whole chapters, because the rephrasing of historical works was considered inaccurate); Guy Yonay, To Steal a Book Is an Elegant Offense: Intellectual Property Law in Chinese Civilization, 8 HARV. J.L. \& TECH. 537, 541 (1995) (referring to Alford's analysis as "convincing" and stating, "[i]n all, the book proposes an excellent theory of legal history in China and of legal change in general").

19. Wei Shi, Cultural Perplexity in Intellectual Property: Is Stealing a Book an Elegant Offense?, 32 N.C. J. INT'L L. \& COM. REGUL. 1, 12 (2006) (arguing that Alford has 
The history of intellectual property rights and private property rights in China is lengthy and complex. Though the history of such property rights in the United States is more linear, it too contains nuances. The following sections provide an overview of intellectual property, personal property, and real property rights in China and the United States.

\section{A. Intellectual Property Rights Across Cultures}

Prior to Alford's work, scholars tended to believe that the concept of copyright protection arose in various societies following their invention of mass printing techniques. ${ }^{20}$ Woodblock printing was invented during the Tang Dynasty (AD 618-907) in China, ${ }^{21}$ and a number of historians trace the development of copyright protection in China to this period. ${ }^{22}$ Other scholars trace the development of copyright law in China to the invention of movable type during the Song Dynasty (AD 960-1279), which would still predate European copyright law by centuries. ${ }^{23}$ Correspondingly,

misunderstood the Confucian perspective); Amy Rosen, China vs. United States: A Cosmopolitan Copyright Comparison, 15 U. PITT. J. TECH. L. POL'Y 1 (2014) (“The scholarship that uses Confucianism to explain why intellectual property is not salient in Chinese culture, such as Alford's, does not consider other factors and severely oversimplifies the complexities of Confucianism."); Ken Shao, The Global Debates on Intellectual Property: What If China Is Not a Born Pirate?, 2010 INTELL. PROP. Q. 341 (contending that Alford presented an incomplete picture concerning the impact of Confucianism on intellectual property protection and enforcement in China); Anna M. Han, To Steal a Book Is an Elegant Offense: Intellectual Property Law in Chinese Civilization by William P. Alford, 36 SANTA CLARA L. REV. 1265, 1269 (1996) (arguing that Alford's book is inconsistent and violates Alford's own earlier admonition to take a comprehensive approach to the study of intellectual property); see also Peter K. Yu, A Half-Century of Scholarship on the Chinese Intellectual Property System, 67 AM. U. L. REv. 1045, 1094-97 (2018) [hereinafter Yu, Half-Century of Scholarship] (discussing Alford's book and the diversity of philosophic and cultural strands within Chinese history and culture).

20. Alford, supra note 6, at 9; Stone, supra note 18; ZHENG \& PENDLETON, supra note 15 , at 11 .

21. Susan Doyle, Jaleen Grove \& Whitney Sherman, History of Illustration 76 (2018); Peter Ganea \& Thomas Pattloch, Intellectual Property LaW in China 205 (Christopher Heath ed., 2005).

22. Guan H. TANG, Copyright AND the Public InTERest In China 65 (2011); Stone, supra note 18; ZHENG \& PENDLETON, supra note 15; Shencheng, supra note 15.

23. TANG, supra note 22, at 65-66; Stone, supra note 18 . Certain of the claims that China invented "copyright protection" are actually rooted in notions of prohibiting plagiarism. Id. Intellectual property law is distinct from preventing plagiarism, though this is a common fallacy among lay individuals. Gregory N. Mandel, Anne A. Fast \& Kristina R. Olson, Intellectual Property Law's Plagiarism Fallacy, 2015 BYU L. REV. 915 (2016) [hereinafter Plagiarism Fallacy]; see also Gregory N. Mandel, What Is IP for? Experiments in Lay and Expert 
the development of Western copyright law has its origins in the invention of the printing press in the fifteenth century and the widespread dissemination of printed matter that this invention enabled. ${ }^{24}$

\section{Intellectual property development in China}

Alford challenged the conventional understanding that Chinese intellectual property law developed in imperial China. ${ }^{25}$ In his view, imperial Chinese law did include restrictions on publication and reprinting of materials, but these restrictions were based on the desire to control the dissemination of heterodox materials, not to protect authorial rights. ${ }^{26}$ Thus, at various historic times, China maintained laws requiring prepublication review of printed matter and prohibiting the unauthorized reproduction of government materials. ${ }^{27}$ These laws were designed to control the dissemination of ideas for purposes related to governmental legitimization, political order, and stability, rather than to provide any form of private intellectual property protection for authors or printers. $^{28}$ Similarly, claims of early Chinese protection of trademarks also reflect the government's exercise of its authority for the purposes of controlling expression and the dissemination of what it viewed as unfavorable symbols. ${ }^{29}$

The absence of intellectual property law in imperial China is not entirely surprising given certain qualities of Eastern and Chinese culture. Eastern cultures tend to view creativity as integrating contributions from many people and sources across time into a current idea or invention. ${ }^{30}$ Confucius famously stated, "I transmit

Perceptions, 90 ST. JOHNS L. REV. 659 (2016) (reporting that intellectual property attorney opinions differ from lay public opinion concerning the basis for intellectual property rights).

24. Sony Corp. of Am. v. Universal City Studios, Inc., 464 U.S. 417, 430 (1984) ("From its beginning, the law of copyright has developed in response to significant changes in technology. Indeed, it was the invention of a new form of copying equipment - the printing press - that gave rise to the original need for copyright protection."); Gary D. Liebcap, Property Rights in Economic History: Implications for Research, 23 EXPLS. ECON. HIST. 227 (1986).

25. AlFORD, supra note 6 , at 9 .

26. Id. at $16-17$.

27. Yu, supra note 9, at 4; ALFORD, supra note 6 , at 17.

28. Yu, supra note 9, at 4; ALFORD, supra note 6, at 17, 24.

29. ALFORD, supra note 6, at 24-25.

30. Gregory N. Mandel, Left-Brain Versus Right-Brain: Competing Conceptions of Creativity in Intellectual Property Law, 44 U.C. DAVIS L. REV. 283, 327 (2010); Stone, supra note 
rather than create," seeing his role as restating and passing on the wisdom and insights of his ancestors without necessarily adding anything new. ${ }^{31}$ Under this view, copying is not only permissible, but a noble way to show respect for one's ancestors; to the contrary, it is private ownership that is immoral. ${ }^{32}$ The emphasis on cooperative effort, the focus on society rather than the individual, and the importance of links to the past all militate against thinking of intellectual creation and innovation as entitled to private property protection. ${ }^{33}$

Conceptions of a sovereign's role in Chinese culture also likely contributed to the lack of intellectual property protection. Traditionally, a ruler in China was viewed as bearing a fiduciary and moral duty to the populace, one that placed the responsibility for nurturing the development of citizens in the ruler's hands. ${ }^{34}$ From this perspective, respect for the ruler's decisions concerning appropriate ideas and material to disseminate is unsurprising. ${ }^{35}$

This understanding helps to explain Chinese governmental restrictions on publication during the imperial period. Although the government did sometimes protect printers from republication of their works, and guilds from the reproduction of certain symbols and materials, the printers and guilds had no individual rights. ${ }^{36}$ Rather, the government exercised its authority in these cases in order to maintain political control over discourse and foster social harmony. ${ }^{37}$

The lack of intellectual property protection in China was not a significant issue for China until trade with the West began to open

18; Carla Hesse, The Rise of Intellectual Property, 700 B.C.-A.D. 2000: An Idea in the Balance, 131 DÆDALUS 26, 27 (2002); Yu, supra note 9, at 16-19; ALFORD, supra note 6, at 19-20. But see WEI Shi, Intellectual Property in the Global Trading System: EU-China Perspective 106-07 (2008) (contending role of Confucian philosophy is overstated and inaccurate).

31. Hesse, supra note 30, at 27; Yu, supra note 9, at 19.

32. Yu, supra note 9, at 16-21; Patrick H. Hu, "Mickey Mouse" in China: Legal and Cultural Implications in Protecting U.S. Copyrights, 14 B.U. INT'L L.J. 81, 104 (1996).

33. Edward J. Walneck, The Patent Troll or Dragon?: How Quantity Issues and Chinese Nationalism Explain Recent Trends in Chinese Patent Law, 31 ARIZ. J. INT'L \& COMPAR. L. 435 (2014); Brent T. Yonehara, Enter the Dragon: China's WTO Accession, Film Piracy and Prospects for the Enforcement of Copyright Laws, 9 UCLA ENT. L. REV. 389 (2002); Stone, supra note 18; ALFORD, supra note 6, at 19-20.

34. ALFORD, supra note 6, at 19-23.

35. $I d$. at 24 .

36. Id. at $24-25$.

37. Id.; Yu, supra note 9 , at 4 . 
up in the nineteenth century. ${ }^{38}$ Initially, this trade involved bulk commodities (such as tea, raw silk, and opium), rendering trademark or other intellectual property protection unnecessary. ${ }^{39}$ As trade relationships evolved and brand names became more important, the need for some form of trademark protection was more pressing. ${ }^{40}$ In part as a result, China entered into treaties with Western nations in the early twentieth century that included trademark, patent, and copyright provisions. ${ }^{41}$ These treaties, however, failed to establish a functional intellectual property regime. For example, although they provided for trademark registration, they did not require registration, identify who could register a mark, or specify the rights provided by registration. ${ }^{42}$ In a similar vein, the patent provisions of the treaties provided that foreign rights would exist only after China created a patent office and enacted patent laws, but provided no timetable for such action. ${ }^{43}$

The end of dynastic Chinese rule in the early twentieth century led to a period of instability before the Kuomintang and Chiang Kai-shek took power in $1928 .{ }^{44}$ China began to enact substantive trademark, copyright, and patent laws at this time. ${ }^{45}$ There remained, however, almost no practical enforcement, or even popular awareness, of such laws during this period. ${ }^{46}$ As Alford writes, "fundamentally, these laws failed to achieve their stated objectives because they presumed a legal structure, and indeed, a

38. AlFORD, supra note 6, at 32-34; Yu, supra note 9, at 5-6.

39. ALFORD, supra note 6 , at 33-38.

40. Id.

41. Id. at 37-38; TANG, supra note 22, at 66 . The first intellectual property laws in China were enacted in the early twentieth century, including the Great Qing Copyright Law of 1910. See NORWOOD F. ALLMAN, HANDBOOK ON THE PROTECTION OF TRADE-MARKS, PATENTS, COPYRIGHTS, AND TRADE-NAMES IN CHINA 112-21 (1924) (providing an English translation of the law); Li Yufeng \& Catherine W. Ng, Understanding the Great Qing Copyright Law of 1910, 56 J. COPYRIGHT SOC'Y U.S.A. 767 (2009).

42. AlFORD, supra note 6 , at 37 .

43. Id. at 38 .

44. Conrad Schirokauer \& Miranda Brown, A Brief History of Chinese CIVILIZATION 286 (2012).

45. AlFORD, supra note 6, at 50-51; Brian J. Safran, A Critical Look at Western Perceptions of China's Intellectual Property System, 3 U. P.R. BUS. L.J. 135, 138 (2012).

46. See ALFORD, supra note 6, at 52-55; Campbell \& Pecht, supra note 7. 
legal consciousness, that did not then exist in China and, most likely, could not have flourished at that time." ${ }^{47}$

The Communist Party and Mao Zedong came to power in 1949 and ushered in a new, socialist political and economic system of government. ${ }^{48}$ Socialist concepts of intellectual property were more consistent with traditional Chinese notions of creation than Western intellectual property ideals had been. ${ }^{49}$ Marx viewed invention and creation as a social, not individual, endeavor directed at a social product. ${ }^{50}$ Though Marxist views of the social nature of creation and Confucian views of the cultural nature of creation were significantly distinct, each conceived of creation as a collective endeavor, not an individual one. Consequently, neither supported private, individual intellectual property rights. ${ }^{51}$ In addition, the socialist perspective of the hierarchical need to control the flow of information to the populace was entirely consistent with the approach that had been taken in imperial China. ${ }^{52}$

Communist China did enact certain types of intellectual property laws in the 1950s. These included a two-track approach to rights in inventions. ${ }^{53}$ The primary track involved the state granting certificates of invention to select inventors. ${ }^{54}$ The state had the right to use and authorize others to use the invention, while the inventor

47. ALFORD, supra note 6 , at 53 .

48. Timothy CHEeK, MAO ZEDONG AND CHINA's Revolutions: A BRIEF History With DOCUMENTS 1 (2002); Safran, supra note 45, at 138-39.

49. AlFORD, supra note 6, at 56-57; Yu, supra note 9, at 21-22.

50. Jing-Kai Syz, Note, Expanding the Patent Law of the People's Republic of China: A Proposal for Patent Protection of Computer Programs, 5 J. CHINESE L. 349, 353 n.18 (1991); see KARL MARX, EARLY WRITINGS 157 (T. B. Bottomore ed. \& trans., 1963) ("Even when I carry out scientific work, etc., an activity which I can seldom conduct in direct association with other men, I perform a social, because human, act."); KARL MARX \& FREDERICH ENGELS, CAPITAL: A CRITIQUe OF POlitical ECONOMY, Volume I 330 n.4 (Frederich Engels, ed., Samuel Moore \& Edward Aveling, trans., 1887) ("A critical history of technology would show how little any of the inventions of the 18th century are the work of a single individual.").

51. ALFORD, supra note 6, at 57; Yonehara, supra note 33, at 74-77.

52. A saying in China during the Cultural Revolution was, "Is it necessary for a steel worker to put his name on a steel ingot that he produces in the course of his duty? If not, why should a member of the intelligentsia enjoy the privilege of putting his name on what he produces?" ALFORD, supra note 6 , at 65 .

53. Id. at 57-58; Peter Feng, InTellectual Property IN China 141-42 (Sweet \& Maxwell Asia 2003); GANEA \& PATTLOCH, supra note 21, at 2.

54. AlFORD, supra note 6, at 57; FENG, supra note 53, at 141-42; GANEA \& PATTLOCH, supra note 21 , at 2 . 
was entitled to recognition and financial rewards based on the savings produced by the invention. ${ }^{55}$ Alternatively, the inventor could receive patent-like rights entitling them to control over the use and distribution of the invention. ${ }^{56}$ Despite these laws, and other laws providing certain exclusive use rights for trademarks, there were only a handful of patents issued in this period and unauthorized infringement was widespread. ${ }^{57}$ There was no equivalent to copyright protection at this time, and the state exercised control over what was published, although the state could provide authors with "basic payments" based on the number of copies printed and a right to prevent alteration of a work. ${ }^{58}$

These limited intellectual property protections were sharply curtailed during the cultural revolutions of the 1960s and replaced with laws that vested intellectual property rights exclusively with the state. ${ }^{59}$ As the government exercised growing control over the dissemination of ideas, materials, and discourse, citizens were encouraged and pressured to not even identify their roles in creation or invention. ${ }^{60}$ Following the end of the Cultural Revolution and arrest of the Gang of Four in the late 1970s, Deng Xiaoping came to power and ushered in the "four modernizations." ${ }^{61}$ China began to revise its approach to intellectual property protection and the precursors to today's laws were introduced. ${ }^{62}$

China started to develop a more modern and Western intellectual property system in 1982, promulgating a new law for the protection of trademarks. ${ }^{63}$ In an effort to incentivize innovation, China also enacted a new and stronger Patent Law in

55. AlFORD, supra note 6, at 57; FENG, supra note 53, at 141-42; GANEA \& PATTLOCH, supra note 21, at 3; Safran, supra note 45, at 138-39; see Gregory N. Mandel, Innovation Rewards: Towards Solving the Twin Market Failures of Public Goods, 18 VAND. J. ENT. \& TECH. L. 303 (2016) (proposing a rewards system based on benefit for public goods inventions).

56. FENG, supra note 53, at 142; GANEA \& PATTLOCH, supra note 21, at 3.

57. ALFORD, supra note 6 , at 61 .

58. Id. at 59-60; $\mathrm{Hu}$, supra note 32 , at 104-05.

59. AlFORD, supra note 6 , at 62-63.

60. Id. at 63-64; see Yu, supra note 6, at 136-37.

61. Richard Baum, Burying MaO: Chinese Politics in the Age of Deng Xiaoping 81 (1996); Libr. OF CONG. Fed. RsCH. Div., ChInA: A COUnTRY StUdy 54-58 (Robert L. Worden et al. eds., 1988); Safran, supra note 45, at 139.

62. Campbell \& Pecht, supra note 7, at 72; Safran, supra note 45, at 139-40.

63. Trademark Law of the People's Republic of China (promulgated by the Standing Comm. Nat'1 People's Cong., Aug. 23, 1982, effective Mar. 1, 1983). 
1984. ${ }^{64}$ These laws were adopted over the objections of some that intellectual property rights were antithetical to socialist principles. ${ }^{65}$ In the early 1990s, China added a copyright law and a law prohibiting unfair competition. ${ }^{66}$ This series of laws represented a major shift in China's approach to intellectual property protection, although initially the Chinese government made only limited efforts to enforce such rights. ${ }^{67}$

As a result, through the 1980s and 1990s, intellectual property protection provided little remedy in China, and intellectual property infringement ran relatively rampant. ${ }^{68}$ In 1989 the United States placed China on its intellectual property Priority Watch List due to concerns about infringement, and in 1994, the United States Trade Representative famously referred to intellectual property rights enforcement in China as "sporadic at best and virtually nonexistent for copyrighted works." ${ }^{69}$ During this period, copyright laws were sometimes used by the state to control the publication and dissemination of printed works. ${ }^{70}$

In the twenty-first century, China re-enacted and amended many of its intellectual property laws, each time making them stronger and providing tougher enforcement rules. ${ }^{71}$ China also

64. Patent Law of the People's Republic of China (promulgated by the Standing Comm. Nat'1 People's Cong., Mar. 12, 1984, effective Apr. 1, 1985).

65. Ganea \& Pattloch, supra note 21, at 3; Mark Sidel, Copyright, Trademark and Patent Law in the People's Republic of China, 21 TEX. INT'L L.J. 259, 282-83 (1986).

66. Copyright Law of the People's Republic of China (promulgated by the Standing Comm. Nat'1 People's Cong., Sept. 7, 1990, effective June 1, 1991); Law Against Unfair Competition of the People's Republic of China (promulgated by the Standing Comm. Nat'l People's Cong., Sept. 2, 1993, effective Dec. 1, 1993).

67. GANEA \& PATTLOCH, supra note 21, at 3; Graham J. Chynoweth, Reality Bites: How the Biting Reality of Piracy in China Is Working to Strengthen Its Copyright Laws, 2 DUKE L. \& TECH. REV. 1, 6 (2003) (referring to China's 1990 copyright law and 1982 trademark law as having "produced more bark than bite"); see ALFORD, supra note 6, at 73-80, 85; Hu, supra note 32, at 105; Campbell \& Pecht, supra note 7, at 74. 33 , at 66

68. ALFORD, supra note 6, at 85-92; Yu, supra note 6, at 146, 165; Yonehara, supra note

69. Cong. Rsch. SERV., Rl30555, China-U.S. Trade AgreEMEnTs: Compliance ISSUES (2000), https://www.everycrsreport.com/files/20001207_RL30555_001f38e95f94b 933570819b037242688bfe13d25.pdf; see Bird, supra note 1, at 339-40.

70. AlFORD, supra note 6, at 79 .

71. The Patent Law was amended in 1992, 2000, and 2008, and a fourth revision of the Patent Law is currently under consideration. Patent Law of the People's Republic of China (promulgated by the Standing Comm. Nat'l People's Cong., Dec. 27, 2008, effective Oct. 1, 2009), http://www.wipo.int/wipolex/en/text.jsp?file_id=178664; Yu, Half-Century of Scholarship, supra note 19, at 1046. The Copyright Law was amended in 2001 and 2010. 
began taking greater steps to enforce its intellectual property laws. ${ }^{72}$ During this period, China signed a number of international intellectual property rights treaties, culminating with China's accession to the World Trade Organization in 2001 and concomitant entrance into the Agreement on Trade Related Aspects of Intellectual Property Rights (TRIPS) in 2001. ${ }^{73}$ Perhaps most significantly, over the last decade China has embarked upon an explicit national policy to improve the creation, use, and protection of intellectual property rights. ${ }^{74}$

These steps have led to significant development of intellectual property rights in China. For example, in 2017 China had the second largest number of international applications filed under the Patent Cooperation Treaty (to the United States) and the third largest number of Madrid Agreement trademark applications (to the United States and Germany). ${ }^{75}$ There are still complaints about the level of intellectual property rights enforcement in China, ${ }^{76}$ and

Copyright Law of the People's Republic of China (promulgated by the Standing Comm. Nat'1 People's Cong., Feb. 26, 2010, effective Apr. 1, 2010), art. 4, http://www.wipo.int/ wipolex/en/text.jsp?file_id=186569; Yu, Half-Century of Scholarship, supra note 19, at 1046. A revised unfair competition law just became effective in 2018. Law of the People's Republic of China Against Unfair Competition (promulgated by the Standing Comm. Nat'l People's Cong., Nov. 4, 2017, effective Jan. 1, 2018); FeNG, supra note 53, at ix; Peter K. Yu, From Pirates to Partners (Episode II): Protecting Intellectual Property in Post-WTO China, 55 AM. U. L. ReV. 901, 906-23, 975 (2006) [hereinafter Yu, Pirates to Partners (Episode II)]; Weightman, supra note 4.

72. Joseph A. Massey, The Emperor Is Far Away: China's Enforcement of Intellectual Property Rights Protection, 1986-2006, 7 CHI. J. INT'L L. 231, 236 (2006); Nguyen, supra note 1, at 789-806; Yu, Pirates to Partners (Episode II), supra note 71, at 911; Jessica Jiong Zhou, Trademark Law \& Enforcement in China: A Transnational Perspective, 20 WIS. INT'L L.J. 415, 431 (2002); Weightman, supra note 4; see also Yu, Half-Century of Scholarship, supra note 19, at 108182 (discussing the evolution of China's intellectual property system from one that transplanted foreign laws to one that is focusing more on internal needs).

73. Agreement on Trade-Related Aspects of Intellectual Property Rights, Apr. 15, 1994, 33 I.L.M. 1197, 1869 U.N.T.S. 299; TANG, supra note 22, at 70-71.

74. State Intell. Prop. Off. of China, China's Intellectual Property Protection in 2008, CNIPA (July 17, 2013), http://english.cnipa.gov.cn/lawpolicy/white/915591.htm.

75. Patent Cooperation Treaty, June 19, 1970, 28 U.S.T. 7645, 1160 U.N.T.S. 231; Who Filed the Most Madrid Trademark Applications in 2017?, WORLD INTELL. PROP. ORG., https://www.wipo.int/export/sites/www/ipstats/en/docs/infographic_madrid_2017. pdf (last visited Jan. 29, 2020); Who Filed the Most PCT Patent Applications in 2017?, WORLD INTELL. PROP. ORG., https://www.wipo.int/export/sites/www/ipstats/en/docs/ infographic_pct_2017.pdf (last visited Jan. 29, 2020).

76. See, e.g., OfF. OF THE U.S. TRADE RePreSENTATIVE, 2017 SPECIAl 301 Report 28 (2017), https://ustr.gov/sites/default/files/301/2017\%20Special\%20301\%20Report\%20FINAL.PDF ("Serious challenges in China continue to confront U.S. intellectual property (IP) right holders with respect to adequate and effective protection of IP, as well as fair and equitable 
such disputes have boiled over into the current trade war between the United States and China, ${ }^{77}$ but there is also no question that China's intellectual property system has developed remarkably rapidly and is continuing to do so. ${ }^{78}$

\section{Intellectual property development in the United States}

In contrast to the laws in China, intellectual property laws have been a mainstay in the United States since the founding of the republic. Patent, copyright, and trademark protection each had significant histories in Britain and continental Europe prior to the formation of the United States, ${ }^{79}$ and intellectual property protection existed in various American colonies prior to the American Revolution in $1776 .{ }^{80}$ The American Constitution grants Congress the power to enact patent and copyright laws in the Intellectual Property Clause of Article I. ${ }^{81}$ Congress wasted no time in exercising this authority, passing the first patent act at the beginning of its first term and the first copyright act the following month. ${ }^{82}$

market access for U.S. persons that rely upon IP protection."); USTR Announces Initiation of Section 301 Investigation of China, OFF. OF THE U.S. TRADE REPRESENTATIVE (Aug. 18, 2017), https://ustr.gov/about-us/policy-offices/press-office/press-releases/2017/august/ustrannounces-initiation-section (announcing a United States Trade Representative investigation of China's intellectual property practices); Request for Consultations by the United States, China - Certain Measures Concerning the Protection of Intellectual Property Rights, WTO Doc. WT/DS542/1 (Mar. 23, 2018) (United States WTO complaint against Chinese intellectual property rights practices); Panel Report, China-Measures Affecting the Protection and Enforcement of Intellectual Property Rights, WTO Doc. WT/DS362/R (adopted Jan. 26, 2009) (United States complaint against Chinese intellectual property rights practices under TRIPS).

77. Supra notes 6,9 . $1058-87$

78. Rana, supra note 1, at 126; Yu, Half-Century of Scholarship, supra note 19, at 1049-50,

79. Trade-Mark Cases, 100 U.S. 82, 92 (1879); CHRISTOPHER MAY \& SUSAN K. SELL, INTELLECTUAL PROPERTY Rights: A CRITICAL History 97 (2006); Crane, supra note 6, at 98.

80. MAY \& SELL, supra note 79, at 105; Edward C. Walterscheid, The Early Evolution of the United States Patent Law: Antecedents (5 Part I), 78 J. PAt. \& Trademark Off. SOC'Y 615 (1996).

81. U.S. CONST. art. I, $\S 8$, cl. 8 ("[The Congress shall have Power t]o promote the Progress of Science and useful Arts, by securing for limited Times to Authors and Inventors the exclusive Right to their respective Writings and Discoveries.").

82. Patent Act of Apr. 10, 1790, 1 Stat. 109 ("An Act to promote the progress of useful Arts"); Copyright Act of May 31, 1790,1 Stat. 124 ("An Act for the encouragement of learning, by securing the copies of maps, charts, and books, to the authors and proprietors of such copies, during the times therein mentioned"). 
American states provided trademark protection under their common law since the United States was formed, ${ }^{83}$ though the first federal trademark law was not enacted until $1870 .{ }^{84}$ This law was struck down by the Supreme Court as unsupported under the Intellectual Property Clause, ${ }^{85}$ but Congress enacted a new trademark act in 1881 pursuant to its Commerce Clause power, and this law was upheld. ${ }^{86}$

These intellectual property laws have remained robust, and generally robustly enforced (at least domestically), since their inception. ${ }^{87}$ During the nineteenth century there was a period when the United States was widely recognized as an international intellectual property pirate. ${ }^{88}$ Subsequently, however, intellectual property rights have been strongly enforced, and the dominant strain of intellectual property discourse in the United States in the twenty-first century has actually concerned whether it is too strong and too strictly enforced. ${ }^{89}$

83. Trade-Mark Cases, 100 U.S. at 92; J. ThOMAS MCCARTHY, MCCARTHY ON TRADEMARKS AND UNFAIR COMPETITION § 5:2 (5th ed. 2018); David S. Welkowitz, Reexamining Trademark Dilution, 44 VAND. L. REV. 531, 532 (1991).

84. Act of July 8, 1870, 16 Stat. 198, 210-12 §§ 77-84 ("An Act to revise, consolidate, and amend the Statutes relating to Patents and Copyrights"); MCCARTHY, supra note 83, at § 5:3.

85. Trade-Mark Cases, 100 U.S. at 99; MCCARTHY, supra note 83, at § 5:3.

86. Act of March 3, 1881, 21 Stat. 502 ("An act to authorize the registration of trademarks and protect the same"); MCCARTHY, supra note 83, at § 5:3.

87. DAN L. BurK \& MARK A. LeMley, The PATENT CRISIS AND How the Courts CAN Solve It 21 (2009); Leah Chan Grinvald, Making Much Ado About Theory: The Chinese Trademark Law, 15 Mich. TeLECOMM. \& TECH. L. REV. 53, 72-73 (2008).

88. B. Zorina Khan \& Kenneth L. Sokoloff, History Lessons: The Early Development of Intellectual Property Institutions in the United States, 15 J. ECON. PERSP. 233, 234-37 (2001); Geoffrey R. Scott, A Comparative View of Copyright as Cultural Property in Japan and the United States, 20 TEMP. INT'L \& COMPAR. L.J. 283, 330 (2006); WILLIAM W. FISHER III, THE GROWTH OF INTELLECTUAL PROPERTY: A HISTORY OF THE OWNERSHIP OF IDEAS IN THE UNITED STATES 11, http://cyber.law.harvard.edu/people/tfisher/iphistory.pdf (last visited Feb. 1, 2020). The United States did not join the Berne Convention, granting reciprocal copyright protection to nationals of other signatories, until 1988. Jane C. Ginsburg, The U.S. Experience with Mandatory Copyright Formalities: A Love/Hate Relationship, 33 COLUM. J.L. \& ARTS 311, 315-18, 322-32 (2010); Orrin G. Hatch, Better Late Than Never: Implementation of the 1886 Berne Convention, 22 CORNELL INT'L L.J. 171, 171-77 (1989). The United States and China are not alone in shifting from weaker to stronger intellectual property systems as their countries become more technologically advanced. Similar shifts have taken place in a number of other countries. Mandel, supra note 7, at 764-65.

89. See generally JAMES BESSEN \& MiChAEL J. MEURER, PATENT FAILURE: HOW JudGES, BUREAUCRATS, AND LAWYERS PUT INNOVATORS AT RISK (2009) (concluding that patent protection should be weakened in certain regards based on an analysis indicating that litigation costs exceed patent-associated profits in certain industries); BURK \& LEMLEY, 
In contrast to Eastern cultures' recognition of the contributions of many across time, Western cultures tend to romanticize individual authors and inventors as the sources of creative works and inventions. ${ }^{90}$ Immanuel Kant developed the romantic concept of an "author-genius," an individual author whose work embodies the author's spirit and who creates something entirely new and unprecedented. ${ }^{91}$ Scholars have analyzed how romantic notions of authorship have worked their way into American copyright law, ${ }^{92}$ a result that is not surprising given that much American copyright law developed as common law during the height of the romantic period in the nineteenth and twentieth centuries. ${ }^{93}$ Americans likewise idolize the achievements of individual, iconic inventors, such as Thomas Edison's light bulb, Alexander Bell's telephone, Jonas Salk's polio vaccine, and Steve Jobs's Apple products. ${ }^{94}$ The common conception of the "eureka" moment of invention, achieved by a single researcher, remains a classic paradigm in the West. ${ }^{95}$ In this cultural context, individualized, private intellectual property rights find an easy home.

supra note 87 , at 3 (discussing various critiques of the availability, strength, and breadth of patent protection).

90. Keith Aoki, (Intellectual) Property and Sovereignty: Notes Toward a Cultural Geography of Authorship, 48 STAN. L. REV. 1293, 1295 (1996); Mandel, supra note 30, at 328; Rana, supra note 1 , at 118 .

91. See generally IMMANUEl KANT, ESSAYS AND TREATISES ON MORAL, Political, AND VARIOUS PHILOSOPHICAL SUBJECTS (William Richardson ed. \& trans., 1798); Martha Woodmansee, The Genius and the Copyright: Economic and Legal Conditions of the Emergence of the 'Author,' 17 EIGHTEENTH-CENTURY STUD. 425, 428-430 (1984) (discussing the development of the idea of an individual, idealized 'author').

92. JAMES BOYLE, SHAMANS, SOFTWARE, AND SPLEENS: LAW AND THE CONSTRUCTION OF THE INFORMATION SOCIETY 53-59 (1996); ROSEMARY J. COOMBE, THE CUlTURAL LiFE OF INTELLECTUAL PROPERTIES: AUtHORSHIP, APPROPRIATION, AND THE LAW 284 (1998); Peter Jaszi, Toward a Theory of Copyright: The Metamorphoses of "Authorship", 1991 DUKE L.J. 455, 496-500.

93. BOYLE, supra note 92 , at 53-59.

94. See Gregory Mandel, Thomas Edison's Patent Application for the Incandescent Light Bulb, in 2 MiLeSTONE DOCUMENTS IN AMERICAN HisTORY 978, 979-80 (Paul Finkelman ed., 2008); Elisabeth Crawford, Nobel: Always the Winners, Never the Losers, 282 SCIENCE 1256, 1257 (1998); Catherine L. Fisk, Removing the 'Fuel of Interest' from the 'Fire of Genius': Law and the Employee-Inventor, 1830-1930, 65 U. CHI. L. REV. 1127, 1160-61 (1998); Jessica Silbey, The Mythical Beginnings of Intellectual Property, 15 GEO. MASON L. REv. 319 (2008).

95. Kevin Dunbar, How Scientists Build Models: InVivo Science as a Window on the Scientific Method, in MODEL-BASEd REASONING IN SCIENTIFIC DisCOVERY 85, 96 (Lorenzo Magnani et al. eds., 1999); Dan L. Burk \& Mark A. Lemley, Policy Levers in Patent Law, 89 VA. L. REV. 1575, 1583 (2003) ("The prototypical innovation contemplated by the patent law is made by an individual inventor working in his garage after hours."); Silbey, supra note 94, 


\section{B. Personal Property and Real Property Across Cultures}

Like intellectual property rights, private rights in real property in America arose with the earliest British colonies and have existed consistently throughout the history of the United States. ${ }^{96}$ Private property rights are a fundamental basis of the American capitalist economy. ${ }^{97}$ Private ownership of real property provides incentives for owners to invest in and develop their property. ${ }^{98} \mathrm{~A}$ common utilitarian view of private property rights perceives that such rights internalize the externalities of property use and consequently incentivize the private owner to put the property to a more socially beneficial use. ${ }^{99}$ In a similar vein and for similar reasons, private ownership of personal property has been an unquestioned constant throughout the United States' history. ${ }^{100}$

Private rights in real and personal property have a more varied history in China. For millennia, the emperor owned and had absolute control over all property, both personal and real. ${ }^{101}$ When the Republic of China was established in 1911, private property still did not receive any protection. ${ }^{102}$ Although a 1930 Civil Code included provisions concerning "Rights over Things," this code

at 330. The image of a person yelling "Eureka!" upon a significant insight is traced to Archimedes, who had been searching for a way to measure the volume of an irregular object (in particular, a crown), getting into a bath and realizing that the volume of water displaced by his body was equal to the amount of his body submerged. He was so excited about his discovery that he ran through the streets shouting "Eureka" (Greek for "I have found it"). DeAn KeIth Simonton, ORIGINS of Genius: DarWinian Perspectives on CREativity 35 (1999).

96. David A. Thomas, Anglo-American Land Law: Diverging Developments from a Shared History Part I: The Shared History, 34 REAL PROP. PROB. \& TR. J. 143 (1999); David A. Thomas, Anglo-American Land Law: Diverging Developments from a Shared History Part II: How AngloAmerican Land Law Diverged After American Colonization and Independence, 34 REAL PROP. PROB. \& TR. J. 295 (1999).

97. Macmillan Dictionary of Modern ECONOMics 54 (David W. Pearce ed., $3 \mathrm{~d}$ ed. 1986) (defining “Capitalism”); BRUCE R. SCOTT, THE CONCEPT OF CAPITALISM 66 (2009).

98. Harold Demsetz, Toward a Theory of Property Rights, 57 AM. ECON. REV. 347, 348 (1967); Eric A. Posner \& E. Glen Weyl, Property Is Only Another Name for Monopoly, 9 J. LEGAL ANALYSIS 51 (2017).

99. Demsetz, supra note 98, at 348, 356; Thomas W. Merrill \& Henry E. Smith, The Morality of Property, 48 WM. \& MARY L. REV. 1849, 1883 (2007).

100. Rana, supra note 1 , at 121.

101. Mo Zhang, From Public to Private: The Newly Enacted Chinese Property Law and the Protection of Property Rights in China, 5 BERKELEY BUS. L.J. 317, 319-20, 324 (2008).

102. Id. at 320 . 
was never applied due to the Japanese occupation and war. ${ }^{103}$ The Communist revolution in 1949 ushered in a new regime. ${ }^{104}$ Traditional Marxist doctrine prohibits private property ownership as contrary to socialism. ${ }^{105}$ Under Mao, private property interests were prohibited and all private property was seized and transferred to state ownership. ${ }^{106}$ As Professor Mo Zhang writes, "[d]uring this period, people were trained to follow the lead of the proletariat (. . . the class of people with no assets or property) $[$,$] . . .$ ma[king] it impossible for Chinese citizens to make any claims of property rights against the government[.]"107

Deng Xiaoping's four modernizations in the late 1970s involved a series of economic reforms and a shift towards more of a market economy. ${ }^{108}$ Part of the transition included greater recognition of private interests and personal liberty in general. ${ }^{109}$ This led to some degree of informal notions of private property rights between private parties, but the government did not formally acknowledge tangible private property rights until it amended its constitution in 2004. ${ }^{110}$ In 2007, China's National People's Congress passed the first law explicitly permitting certain private property rights, including rights over income and savings, housing, and a variety of tangible items. ${ }^{111}$ Under this law, private parties still cannot own

103. Id.

104. Columbia Chronologies of Asian History AND Culture 70 (John S. Bowman ed., 2000); Richard Goldstein, Copyright Relations Between the United States and the People's Republic of China: An Interim Report, 10 BROOK. J. INT'L L. 403, 410 (1984); Sidel, supra note 65 , at 261 .

105. Hans-Hermann Hoppe, A TheOry of SOCIAlism and CAPITALISM: ECONOMICS, POLITICS AND ETHICS 2 (1989); Benjamin W. James, Expanding the Gap: How the Rural Property System Exacerbates China's Urban-Rural Gap, 20 COLUM. J. ASIAN L. 451, 456 (2007).

106. THE Writings of MAO ZEDONG, 1949-1976: VOLUME I, SEPTEMBER 1949-DECEMBER 1955, at 351 (Michael Y. M. Kau \& John K Leung eds., 1986); Daniel J. Morrissey, Managing the Wealth of Nations: What China and America May Have to Teach Each Other About Corporate Governance, 68 SMU L. REV. 831, 833 (2015); William D. Soileau, Past is Present: Urban Real Property Rights and Housing Reform in the People's Republic of China, 3 PAC. RIM L. \& POL'Y J. 299 (1995); Zhang, supra note 101, at 324-26.

107. Zhang, supra note 101 , at 320-21.

108. Columbia Chronologies of Asian History AND Culture, supra note 104; Soileau, supra note 106.

109. Soileau, supra note 106; Zhang, supra note 101, at 323.

110. Zhang, supra note 101, at 336.

111. Ryan van Steenis, From Mao to Madison and Back: An Examination of China's National Property Law and Its Diminished Potential, 23 TEMP. INT'L \& COMP. L.J. 35 (2009); Zhang, supra note 101 , at $336-37$. 
real property, which is owned by the state or other public entities. ${ }^{112}$ Private parties can own the right to use certain real property, as well as own any buildings on the land, while renting the land on long-term leases lasting up to seventy years. ${ }^{113}$ The law also includes protection for private owners against illegal seizures by the government. ${ }^{114}$ The evolution of private property rights in China was based on a desire to stimulate "people's initiative to create and accumulate wealth and to promote social harmony" in an effort to drive the economy. ${ }^{115}$ As with intellectual property rights, China's shift towards granting private protection for personal and real property rights was based on a desire to incentivize investment and development. China is currently working on a comprehensive civil code, one that is anticipated to further strengthen private property rights. ${ }^{116}$

Given the differing histories of intellectual, personal, and real property rights in China and the United States, it is not surprising that people in these two countries have differing conceptions of property rights. The following section details current understanding around these differences.

\section{Psychological Conceptions of Property}

A variety of psychological research has explored the cultural differences between Americans and Chinese. ${ }^{117}$ Prior research in social and cultural psychology has found differences in how East Asians versus Americans and Europeans tend to view

112. Zhang, supra note 101, at 355. In China, real property in urban areas is owned by the state and real property in rural areas is owned by collectives. Id.

113. Id. at 355-56. For residential buildings, this term may be automatically renewed. Id. at 356.

114. Property Law of the People's Republic of China, Order No. 62, Art. 42 (Mar. 16, 2007), http://www.china.org.cn/china/LegislationsForm2001-2010/2011-02/11/ content_21897791.htm; Zhang, supra note 101, at 359 (describing the provisions for compensation in the case of expropriation, though noting that the law does not guarantee due process in relation to takings).

115. Jim Yardley, China Nears Passage of Landmark Property Law, N.Y. Times (Mar. 9, 2007), https:// www.nytimes.com/2007/03/09/business/09yuan.html.

116. Javier C. Hernandez \& Owen Guo, China Pushes Legal Overhaul That Would Bolster State Power, N.Y. TIMES (Mar. 15, 2017), https://www.nytimes.com/2017/03/15/world/ asia/xi-jinping-legal-overhaul.html.

117. Chen, supra note 12, at 84-91; Chia et al., supra note 12, at 23-30; Ji et al., supra note 12, at 943-55; Morris et al., supra note 12, at 949-71; Stipek, supra note 12, at 616-29. 
themselves. ${ }^{118}$ For example, East Asians have been found to have a more collectivist self-construal, viewing the self in terms of one's relation to others, and holding what is considered an interdependent view of the self, in which people value their social group's or family's goals, needs, and abilities. ${ }^{119}$ In contrast, North Americans and Europeans have been found to be more individualistic, viewing the self as separate from others, and holding what is considered to be a more independent view of the self, emphasizing one's own distinct goals, needs, and abilities. ${ }^{120}$ Most relevant to the present work, a meta-analysis of numerous studies found that Chinese adults are more collectivistic and American adults are more individualistic. ${ }^{121}$

These apparent cultural differences are likely interwoven with the distinct histories of property rights in China and America. That is, cultural differences may have led to some of the differences in each culture's treatment of personal property, real property, and intellectual property, and the differing historical paths simultaneously may also produce differing cultural and social attitudes towards property rights today.

Despite rich debates over the last several decades concerning differences between American and Chinese attitudes towards intellectual property rights, and despite the critical effects that such attitudes can have on intellectual property compliance and economic markets, to our knowledge no one has ever actually tried to test these attitudes. The studies reported here provide the first attempts to explore cross-cultural differences in attitudes towards intellectual property rights, personal property rights, and real property rights between Americans and Chinese. The somewhat counterintuitive results provide important lessons for the future of international intellectual property rights enforcement and discourse.

118. Markus et al., supra note 13, at 223-53; Oyserman et al., supra note 13, at 255-79; Triandis, supra note 13 , at 907-24.

119. Markus et al., supra note 13, at 223-53; Daphna Oyserman, Heather M. Coon \& Markus Kemmelmeier, Rethinking Individualism and Collectivism: Evaluation of Theoretical Assumptions and Meta-Analyses, 128 PsYCH. BULL. 3, 3-72 (2002).

120. Markus et al., supra note 13, at 223-53; Oyserman et al., supra note 119.

121. Oyserman et al., supra note 119. This meta-analysis analyzed 83 total studies, nine of which directly compared the United States and China (not counting Taiwan and Hong Kong). Id. 


\section{EXPERIMENTS ON CROSS-CULTURAL PERCEPTIONS OF PROPERTY RIGHTS}

As the above historical accounts reveal, the formal laws on the books do not necessarily translate into how law will be implemented in society. Rather, the enforcement and effectuation of law is subject to the political and social culture surrounding the formal law. ${ }^{122}$ In order to better comprehend how legal rules play out in practice, it is necessary to understand the social and intellectual environment in which the rules exist. The studies presented below examine the relation between law and culture in the United States and China for different types of property rights. Study 1 provides a pilot examination and Study 2 presents the primary examination that is the basis for the analysis in Part III.

\section{A. Study 1: Cross-Cultural Study of American College Students}

Our first examination of cross-cultural perceptions of property rights was conducted by comparing college students from different cultural backgrounds. As in all of the studies reported here, we selected adult students who were not engaged in the study of law. In order to explore cross-cultural attitudes, we recruited White American, East Asian American, and East Asian International college students. White American and East Asian American participants were adults born in the United States who had not lived outside of the United States. East Asian participants were adults born in an East Asian country who arrived in the United States at sixteen years of age or older. ${ }^{123}$ These criteria were determined before the study began.

122. See, e.g., Robert C. Ellickson, Of Coase and Cattle: Dispute Resolution Among Neighbors in Shasta County, 38 STAN. L. REV. 623, 628 (1986) (discussing sociological research finding that, because laws are costly to learn and enforce, parties often ignore the formal law and instead create their own systems of informal norms and enforcement that work within their relationships and context).

123. In an effort to attract a sufficient population size, as well as other reasons, it was more practical to select East Asian participants generally as opposed to limiting Study 1 to Chinese students. As discussed below, Study 2 contains a cohort of solely Chinese participants. 


\section{Study 1 methodology}

Participants. Participants were college students recruited at a large university in the Pacific Northwest through the university's online participant pool system that compensated participants with course credit for completing an online survey. The final sample included sixty White Americans, seventy-seven East Asian Americans, and sixty-one East Asians. ${ }^{124}$ The median ages and gender distribution of the three populations were similar. ${ }^{125}$ The study materials included (1) vignette evaluations, (2) legal compliance questions, (3) a self-construal scale, and (4) demographic questions. ${ }^{126}$ Each of these sections is described below.

Vignette evaluations. Participants received twelve vignettes reflecting a 4 (property domain) X 3 (transfer type) design. The four property domains were: (1) intellectual property protected by a patent (copying of a patented vaccine), (2) intellectual property protected by a copyright (copying of a copyrighted textbook), (3) personal property (taking a textbook), and (4) real property (trespassing on land). The three property transfer types were: (1) someone taking another person's private property for his/her own benefit (private-for-private), (2) someone taking another person's private property for a public use benefiting third parties (private-for-public), and (3) a public entity taking private property for a public use benefiting third parties (public-for-public).

Following each vignette, participants were asked their "opinion about whether such action should or should not be allowed, regardless of what the law might actually be." Specifically, participants were asked, "In your opinion, should [the property user's] action be legally allowed?" (legal permissibility). Participants

124. An additional 30 American participants completed the study, but were excluded from analyses either for not being the target race/ethnicity $(n=15)$, not being born in the United States $(n=2)$, or having lived outside of the United States for a significant period of time $(\mathrm{n}=13)$. An additional 41 East Asian participants completed the study but were excluded from analyses either for not being the target race/ethnicity $(n=1)$ or arriving in the United States before 16 years of age $(n=40)$.

125. White Americans: median age $=19.13$ years, $\mathrm{SD}=1.74$ years; $55 \%$ female. East Asian Americans: median age $=19.38$ years, $\mathrm{SD}=1.64$ years; $54 \%$ female. East Asians: median age $=20.23$ years, $\mathrm{SD}=3.32$ years; $61 \%$ female.

126. The online survey also included two short questions that are not included here, as they were pilot items for a future study examining perceptions of eminent domain. These questions were the very last items presented to participants. 
reported their answers to each question using a slider scale ranging from 0 (definitely not allowed) to 100 (definitely allowed), which was anchored at 50 when the item was presented to participants. After this question, participants were asked, "Laws should be most concerned with the rights of: [intellectual] property owners vs. [intellectual] property users" (protection of rights). Participants again reported their answers on a slider scale ranging from 0 (owners) to 100 (users) that was anchored at 50 when presented to participants.

Legal compliance questions. Participants were next asked to answer two questions about their general level of support for property laws: (1) "How important is it for people to comply with property rights?" and (2) "How important is it for people to comply with intellectual property rights?" Participants responded to these questions using a slider scale ranging from 0 (extremely not important) to 100 (extremely important), which was anchored at 50 when the item was presented to participants. Because participants' scores on the two opinion questions were highly correlated to one another, ${ }^{127}$ we created a new factor to represent a construct we call Compliance Support, which is the average of scores on these two items. Higher Compliance Support scores indicate greater support for the compliance with property rights.

Self-Construal Scale. To measure participants' independent and interdependent self-construals (typically associated with Western and East Asian cultures, respectively), participants completed the Self-Construal Scale. ${ }^{128}$ This thirty-item scale includes a fifteen-item scale referring to an independent self-construal (e.g., "I enjoy being unique and different from others in many respects") and a fifteenitem scale referring to an interdependent self-construal (e.g., "Even when I strongly disagree with group members, I avoid an argument"). Participants were able to provide a response ranging from "strongly disagree" (1) to "strongly agree" (7). Critically, participants received separate scores for interdependent selfconstrual $^{129}$ and independent self-construal, ${ }^{130}$ as they were

127. $r=.67, p<.001$.

128. Theodore M. Singelis, The Measurement of Independent and Interdependent SelfConstruals, 20 PERSONALITY \& SOC. PSYCH. BULl. 580 (1994).

129. White Americans: Cronbach's alpha $=.70$; East Asian Americans: Cronbach's alpha = .79; East Asian: Cronbach's alpha $=.83$.

130. White Americans: Cronbach's alpha $=.66$; East Asian Americans: Cronbach's alpha = .75; East Asian: Cronbach's alpha = .72. 
designed to be separate constructs, each reflecting the average score of the fifteen pertinent items.

Demographic questions. The demographic section of the survey included questions about participants' age, gender, race/ethnicity, birthplace, age upon arrival in the United States, residence outside of the United States, political ideology, type of residence, and previous experience with law or law-related fields. For the lawrelated experience items, participants were asked whether they themselves had "any current or past experience with law or lawrelated fields (i.e., taken law classes or worked as a law clerk)" and whether they had "any close friends or family working in law or law-related fields[.]" Demographics by participant group are reported in Table 1. 
Table 1. Demographics of Participants in Study 1.

\begin{tabular}{|c|c|c|c|}
\hline Variable & $\begin{array}{l}\text { White } \\
\text { American }\end{array}$ & $\begin{array}{l}\text { Asian } \\
\text { American }\end{array}$ & East Asian \\
\hline Age (in years) & $\mathrm{M}=19.13(1.74)$ & $\mathrm{M}=19.38(1.64)$ & $\mathrm{M}=20.23(3.32)$ \\
\hline \multicolumn{4}{|l|}{ Gender } \\
\hline Male & $45 \%$ & $46 \%$ & $39 \%$ \\
\hline Female & $55 \%$ & $53 \%$ & $61 \%$ \\
\hline Other & $0 \%$ & $1 \%$ & $0 \%$ \\
\hline \multicolumn{4}{|l|}{ Residence } \\
\hline Urban & $44 \%$ & $27 \%$ & $82 \%$ \\
\hline Suburban & $45 \%$ & $65 \%$ & $15 \%$ \\
\hline Small Town & $8 \%$ & $4 \%$ & $3 \%$ \\
\hline Rural & $3 \%$ & $4 \%$ & $0 \%$ \\
\hline $\begin{array}{l}\text { Political } \\
\text { Ideology }\end{array}$ & $\begin{array}{l}M=34.60 \\
(26.76)\end{array}$ & $\begin{array}{l}M=33.06 \\
(18.96)\end{array}$ & $\begin{array}{l}M=48.95 \\
(18.66)\end{array}$ \\
\hline \multicolumn{4}{|l|}{$\begin{array}{l}\text { Own Law } \\
\text { Experience }\end{array}$} \\
\hline Yes & $12 \%$ & $8 \%$ & $7 \%$ \\
\hline No & $88 \%$ & $92 \%$ & $93 \%$ \\
\hline \multicolumn{4}{|l|}{ Family Law } \\
\hline Yes & $28 \%$ & $18 \%$ & $12 \%$ \\
\hline No & $72 \%$ & $82 \%$ & $88 \%$ \\
\hline
\end{tabular}




\section{Study 1 results}

Responses to the legal permissibility and protection of rights vignette items were analyzed in two 4 (property domain: patent vs. copyright vs. personal vs. land) $\times 3$ (transfer type: private-forprivate vs. private-for-public vs. public-for-public) $\times 3$ (group: White American vs. East Asian American vs. East Asian) mixed measures ANOVAs ${ }^{131}$ with group as a between-subjects factor and domain and transfer type as within-subjects factors. The discussion below provides a detailed statistical report of the results. The implications of the results of both Study 1 and Study 2 are discussed in Part III.

Analyses of the legal permissibility items revealed statistically significant variation across the different property domains. ${ }^{132}$ Participants believed that using someone else's personal property $(M=20.54, S D=18.32)$ should be less permissible than using someone else's intellectual property (patent: $M=32.70, S D=20.68$; copyright: $M=34.66, S D=20.53)$ or land $(M=34.15, S D=24.31) .{ }^{133}$ The responses to the patent, copyright, and land scenarios, however, did not vary from one another (all $p s=1.0)$.

The type of transfer also had a significant effect on respondents' property rights evaluations. ${ }^{134}$ Participants believed that privatefor-private uses of property $(M=18.10, S D=14.88)$ should be less allowed than private-for-public uses of property $(M=35.12, S D=$ 21.86), or public-for-public uses of property $(M=38.32, S D=$ 21.37). ${ }^{135}$ Further, participants believed that private-for-public uses of property should be less allowed than public-for-public uses of property $(p=.022)$. However, whether a respondent was White American, East Asian American, or East Asian had no significant effect on their evaluation of legal permissibility $(p=.405)$.

131. The analysis of variance (ANOVA) is a statistic designed to isolate and evaluate the effect of independent variables on a continuous dependent variable. PAul G. Hoel, InTROduction To MATHEMATICAl Statistics 311-12 (5th ed. 1984); J. Rick TURNER \& JULIAN THAYER, INTRODUCTION TO ANALYSIS OF VARIANCE: DESIGN, ANALYSIS \& INTERPRETATION (2001).

132. $F(3,462)=33.71, p<.001, \eta p 2=.18$.

133. Pairwise comparisons (Bonferroni corrected): using personal property should be less permissible than using intellectual property, $p \mathrm{~s}<.001$, or land, $p<.001$.

134. $F(2,308)=131.18, p<.001, \eta p 2=.46$.

135. Pairwise comparisons (Bonferroni corrected): private-for-private uses should be less allowed than private-for-public uses, $p<.001$, or public-for-public uses, $p<.001$. 
The effects identified above were qualified by a significant interaction between the property domain and transfer type at issue. ${ }^{136}$ The differentiation based on transfer type existed for three of the four property domains-in the patent, copyright, and personal property scenarios, participants were more strict about private-for-private transfers compared with private-for-public transfers (all ps <.001), and more strict about private-for-private transfers compared with public-for-public transfer (all $p \mathrm{~s}<.001$ ), but judged private-for-public and public-for-public transfers as similar (all $p s=1.0)$. This pattern did not hold for the land scenarios, as participants judged all three transfer types similarly (all $p s>.083)$.

There was also a significant interaction between race/ethnicity and transfer type. ${ }^{137}$ The effect of transfer type noted above held within two of the three groups - in the White American and East Asian groups, participants were more strict about private-forprivate transfers compared to private-for-public transfers (all $p s<$ .001 ), and more strict about private-for-private transfers compared to public-for-public transfers (all $p s<.001$ ), but judged private-forpublic and public-for-public transfers as similar (all ps $>$.899). However, this pattern did not hold for the East Asian Americans, as participants not only were more strict about private-for-private transfers compared to private-for-public transfers $(p<.001)$, and more strict about private-for-private transfers compared to publicfor-public transfers $(p<.001)$, but also were more strict about private-for-public transfers compared to public-for-public transfers $(p=.011)$. No other interactions were significant (all $p s>.336)$. The results of the legal permissibility questions are displayed in Figure 1 and Table 2.

136. $F(6,924)=32.33, p<.001, \eta p 2=.17$.

137. $F(4,308)=2.96, p=.020, \eta p 2=.04$. 
Figure 1. Study 1: Legal Permissibility Ratings of Vignettes by Transfer Type, Domain, and Group. Higher values represent greater legal permissibility.

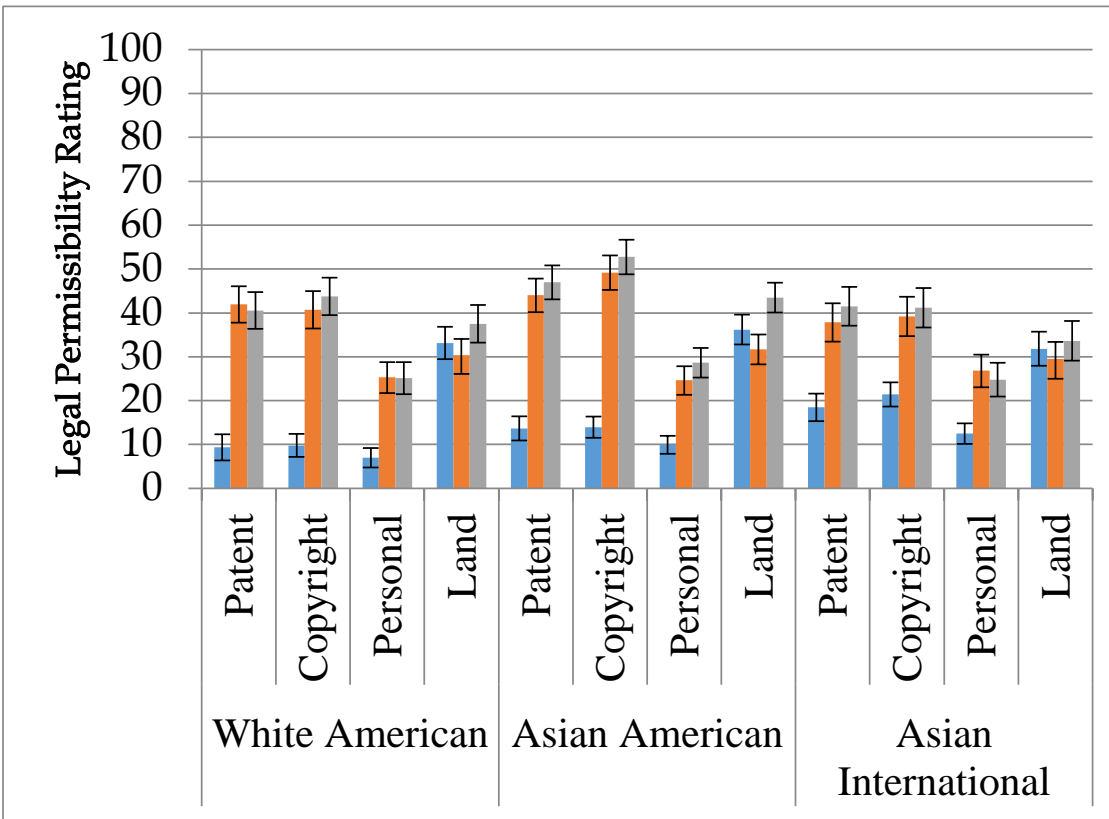

$\square$ Private for Private $\square$ Private for Public $\square$ Public for Public 
Table 2. Study 1: Legal Permissibility Ratings of Vignettes by Transfer Type, Domain, and Group. Higher values represent greater legal permissibility.

\begin{tabular}{|l|llll|}
\cline { 2 - 5 } \multicolumn{1}{c|}{} & \multicolumn{4}{c|}{ White American } \\
\cline { 2 - 5 } \multicolumn{1}{c|}{} & Patent & Copyright & Personal & Land \\
\hline Private for Private & 9.35 & 9.8 & 6.98 & 33.14 \\
Private for Public & 41.96 & 40.71 & 25.37 & 30.37 \\
Public for Public & 40.55 & 43.76 & 25.12 & 37.51 \\
\hline
\end{tabular}

\begin{tabular}{|l|llll|}
\cline { 2 - 5 } \multicolumn{1}{c|}{} & \multicolumn{4}{c|}{ Asian American } \\
\cline { 2 - 5 } \multicolumn{1}{c|}{} & Patent & Copyright & Personal & Land \\
\hline Private for Private & 13.67 & 13.95 & 9.93 & 36.2 \\
Private for Public & 44.03 & 49.17 & 24.7 & 31.67 \\
Public for Public & 46.95 & 52.73 & 28.63 & 43.48 \\
\hline
\end{tabular}

\begin{tabular}{|l|llll|}
\cline { 2 - 5 } \multicolumn{1}{c|}{} & \multicolumn{4}{c|}{ East Asian } \\
\cline { 2 - 5 } \multicolumn{1}{c|}{} & Patent & Copyright & Personal & Land \\
\hline Private for Private & 18.46 & 21.41 & 12.48 & 31.83 \\
Private for Public & 37.87 & 39.2 & 26.89 & 29.5 \\
Public for Public & 41.5 & 41.17 & 24.78 & 33.63 \\
\hline
\end{tabular}

Similar to the legal permissibility responses, analyses of the protection of rights vignettes also revealed a statistically significant effect of property domain on participants' responses. ${ }^{138}$ Participants were more likely to believe that laws should be more concerned with protecting the rights of property owners relative to property users in the case of personal property $(M=26.32, S D=27.31)$ as

138. $F(3,420)=8.99, p<.001, \eta p 2=.06$. 
compared to both forms of intellectual property tested (patent: $M=$ 34.53, $S D=30.13$; copyright: $M=35.07, S D=29.24)$, and as compared to land $(M=32.04, S D=26.46) .{ }^{139}$ Responses to the two intellectual property cases and land again did not differ (all $p$ s > .808).

Transfer type also had a significant effect on protection of rights evaluations. ${ }^{140}$ Respondents were more likely to believe that laws should be more concerned with protecting the rights of property owners in private-for-private uses of property $(M=23.64, S D=$ $26.84)$ compared to both the private-for-public uses of property $(M$ $=36.20, S D=28.73)$, and the public-for-public uses of property $(M$ $=36.14, S D=29.29) .{ }^{141}$ Responses to the private-for-public uses of property and public-for-public uses of property did not differ $(p=$ 1.0). As with the legal permissibility questions, there was no significant effect of participants' race/ethnicity on their responses $(p=.284)$.

These protection of rights effects were qualified by a significant interaction between the property domain and transfer type. ${ }^{142}$ This interaction revealed that the main effect of transfer type held within three of the four domains. In the patent, copyright, and personal property scenarios, participants were more likely to believe that the law should be concerned with the rights of the owner in privatefor-private transfers compared to private-for-public transfers (all ps $<.001$ ), as well as more likely to be concerned with rights of the owner in private-for-private transfers compared to public-forpublic transfers (all $p s<.001$ ), but judged private-for-public and public-for-public transfers as similar (all $p \mathrm{~s}=1.0$ ). However, this pattern did not hold for the land scenarios, where participants judged all three transfer types similarly (all $p$ s $>.425$ ).

There was also a significant interaction between participants' race/ethnicity and property domain responses, revealing that the main effect of domain occurred in the White American group, but

139. Pairwise comparisons (Bonferroni corrected): laws should protect the rights of property owners relative to property users in the case of personal property compared to both forms of intellectual property, $p \mathrm{~s}<.001$, and land, $p=.025$.

140. $F(2,280)=37.73, p<.001, \eta p 2=.037$.

141. Pairwise comparisons (Bonferroni corrected): laws should be more concerned with protecting the rights of property owners in private-for-private uses of property compared to both the private-for-public uses of property, $p<.001$, and the public-for-public uses of property, $p<.001$.

142. $F(6,840)=13.32, p<.001, \eta p 2=.087$. 
not the other two groups. ${ }^{143}$ White American participants were more likely to believe that laws should be more concerned with protecting the rights of property owners in the case of personal property compared to both forms of intellectual property and land (all $p$ s <.001), with the intellectual property and land domains being judged similarly (all $p \mathrm{~s}=1.0$ ). East Asian American participants, on the other hand, were (marginally) more likely to believe that laws should be more concerned with protecting the rights of property owners in both the personal property and land domains compared to both intellectual property domains (all $p s<$ .065). In this group, the personal property and land domains were judged similarly to one another $(p=1.0)$, and the two intellectual property domains were judged similarly to one another $(p=1.0)$. Further, the East Asian participants judged all four domains similarly with respect to whether the law should be concerned with rights of property owners or property users (all $p s>.160$ ). No other interactions were significant (all $p$ s $>$.317).

Turning to the questions about the importance of complying with laws, the three groups (White American, East Asian American, and East Asian) differed significantly in the degree to which they endorsed compliance with property and intellectual property laws. ${ }^{144}$ East Asian participants' Compliance Support $(M=83.59$, $S D=14.91)$ was significantly higher than that of both East Asian Americans $(M=75.45, S D=16.75)$ and White Americans $(M=$ 75.90, $S D=19.23) .{ }^{145}$ The Compliance Support of East Asian American and White American participants did not differ significantly $(p=.988)$. Each of the race/ethnicity groups scored significantly above the midpoint of the scale (50), indicating a tendency to prefer compliance with property and intellectual property law. ${ }^{146}$

The three race/ethnicity groups differed significantly on their tendency to endorse independent self-construal ${ }^{147}$ but not on their

143. $F(3,420)=2.72, p=.013, \eta p 2=.037$.

144. $F(2,186)=4.39, p=.014, \eta p 2=.05$, one-way ANOVA.

145. Posthoc Tukey tests: East Asian participants' Compliance Support was significantly higher than that of East Asian American participants $(p=.019)$ and White Americans $(p=.043)$.

146. White American: $t(57)=17.15, p<.001$; East Asian American: $t(73)=13.07, p<.001$; East Asian: $t(56)=10.17, p<.001$.

147. $F(2,193)=6.63, p=.002, \eta p 2=.06$. 
tendency to endorse interdependent self-construal. ${ }^{148}$ White American participants $(M=4.90, S D=0.57)$ had significantly higher independent self-construal than East Asian participants $(M$ $=4.51, S D=0.59 ; p=.001)$, but were no different than East Asian American participants $(M=4.69, S D=0.59 ; p=.103)$. East Asian and East Asian American participants did not differ in their tendency to endorse independent self-construal $(p=.174)$.

Having completed Study 1 as a pilot study on cross-cultural attitudes towards property rights, we turned to Study 2.

\section{B. Study 2: Cross-Cultural Study of American and Chinese College Students}

Study 1 yields several tantalizing results concerning differences in attitudes towards property across cultures. Because Study 1 recruited only students at an American university, however, there is a significant chance that selection effects affected the East Asian participant population. That is, students from East Asian countries who attend college in the United States, even though they grew up in East Asia, may not be reflective of East Asian attitudes towards property rights in general. For Study 2, we turned to a comparison of college students at an American university and at a Chinese university. As in Study 1, none of the participants were engaged in the study of law.

\section{Study 2 methodology}

Participants. Our final group of participants included 101 White American college students from a university in the Pacific Northwest (who had not participated in Study 1) and 102 Chinese college students from a university in the Yunnan region of China. ${ }^{149}$ The gender distribution of the study populations was similar, and the Chinese participants averaged slightly older than the Americans. ${ }^{150}$ White American participants were recruited both

148. $F(2,192)=1.56, p=.213, \eta p 2=.02$.

149. Yunnan is a large province in southern China, known for its diverse population, and is significantly less economically developed than Beijing or Shanghai. Ping-chia Kuo \& Robert Lee Suettinger, Yunnan, ENCYClOPAEDIA BRITANNICA (Nov. 8, 2016), https:// www.britannica.com/place/Yunnan.

150. White American college students: Mage $=20.12$ years, $S D=3.43$ years; $67 \%$ female. Chinese college students: Mage $=23.42$ years, $S D=5.57$ years; $66 \%$ female. 
through a university online participant pool system that compensated participants with course credit and through postings around campus that compensated participants with a $\$ 5$ gift card for completing an online survey. Chinese participants were recruited through an announcement during their university courses, in which they were invited to visit a survey platform (Sojump.com) to complete the survey online. Upon completion of the survey, participants were compensated with 20 Yuan, which was determined by professors familiar with American and Chinese college students to provide a roughly similar incentive to the $\$ 5$ gift card. ${ }^{151}$

To be included in the analyses, White American participants had to be born in the United States and to not have lived outside of the United States for a significant time. Chinese students had to be born in China and to not have lived outside of China for a significant time. All participants were required to be at least eighteen years of age and no older than forty years of age. ${ }^{152}$

Both the United States and China have rich cultural, ethnic, and racial variation within the societies. Our study, focused on White American college students and on Chinese college students from a single region in order to provide a comparison, does not explore this intracountry diversity, a topic that is worthy of further research. Nevertheless, we use the general terms "American" and "Chinese" in the text that follows for ease of discussion.

As in Study 1, the study materials included (1) vignette evaluations, (2) legal compliance questions, (3) a self-construal scale, and (4) demographic questions. The survey material for the American participants was written in English, and the survey material for Chinese participants was written in Mandarin Chinese. The survey materials were translated from English by a native Mandarin speaker and were then back-translated to English by different bilingual translators in order to confirm the translation.

Vignette evaluations. The vignettes were the same as those used in Study 1, with the exception of the three vignettes depicting use

151. 20 Yuan was worth roughly $\$ 3.00$ at the time of the study.

152. An additional 19 participants completed the study in the United States but were excluded from analyses for either not being the target race/ ethnicity $(n=5)$ or having lived outside of the United States $(n=14)$. An additional 28 participants completed the study as part of the Chinese group but were excluded from analyses for either not being born in China $(n=8)$, having lived outside of China $(n=9)$, or being outside of the target ages $(n=11)$. 
of someone's real property. The land vignettes were modified to be about taking someone else's land, rather than trespassing on land (as they were in Study 1). This change was made in order to better align the real property scenario with the intellectual property and personal property scenarios, as we were concerned that a single trespass on real property, causing no damage, might not have been a significant enough incursion on property rights relative to the other vignettes. None of the vignettes provide for compensation for the taken property rights.

As in Study 1, participants read twelve total vignettes (that is, for each of the four property domains, vignettes involving a private-for-private transfer, a private-for-public transfer, and a public-for-public transfer). Following each vignette, participants were asked, "In your opinion, should the property user's action be legally allowed?" Participants reported their answers to each question using a slider scale ranging from 0 (definitely not allowed) to 100 (definitely allowed), which was anchored at 50 when the item was presented to participants. Participants were not asked the second dependent variable question from Study 1 (concerning whether the law should be primarily concerned with the rights of [intellectual] property owners or users), because the responses in Study 1 were largely redundant, and removing the question addressed concerns about time limits in this study.

Legal compliance questions. The legal compliance questions from Study 1 were slightly modified, such that participants were asked three questions: (1) "How important is it for people to comply with property rights in land?," (2) "How important is it for people to comply with personal property rights (such as peoples' clothes or books)?," and (3) "How important is it for people to comply with intellectual property rights?" Participants responded to the questions using a slider scale ranging from 0 (extremely not important) to 100 (extremely important), which was anchored at 50 when the item was presented to participants. Because participants' scores on the three opinion questions were highly correlated to one another, ${ }^{153}$ we created a new factor to represent a construct we call Compliance Support, which is the average of scores on these three items. Higher Compliance Support scores indicate greater support for the compliance with property rights.

153. American: Cronbach's alpha $=.76$; Chinese: Cronbach's alpha $=.93$. 
Self-Construal Scale. As in Study 1, participants completed the Self-Construal Scale. ${ }^{154}$ Again, both the independent ${ }^{155}$ and interdependent ${ }^{156}$ scales showed high reliability among the items within each scale. Therefore, the fifteen items on each scale were averaged to create an Independent Self-Construal score and an Interdependent Self-Construal score for each participant.

Demographic questions. The demographic section of the survey included questions about participant age, gender, race/ethnicity, birthplace, age upon arrival in the United States/China, residence outside of the United States/China, academic major, year at university, and experience with law. For the law-related experience item, participants were asked whether they had "any current or past experience with law or law-related fields (i.e., taken law classes or worked as a law clerk)." Responses are provided in Table 3.

154. Singelis, supra note 128 , at 580 .

155. American: Cronbach's alpha $=.73$; Chinese: Cronbach's alpha $=.87$.

156. American: Cronbach's alpha $=.69$; Chinese: Cronbach's alpha $=.91$. 
Table 3. Demographics of Participants in Study 2.

\begin{tabular}{|c|c|c|}
\hline Variable & American & Chinese \\
\hline Age (in years) & $\mathrm{M}=20.12(3.43)$ & $\mathrm{M}=23.42(5.58)$ \\
\hline \multicolumn{3}{|l|}{ Gender } \\
\hline Male & $32 \%$ & $34 \%$ \\
\hline Female & $66 \%$ & $66 \%$ \\
\hline Other & $1 \%$ & $0 \%$ \\
\hline Do not wish to report & $1 \%$ & $0 \%$ \\
\hline \multicolumn{3}{|l|}{ Academic Major } \\
\hline Psychology & $6 \%$ & $15 \%$ \\
\hline Business & $24 \%$ & $26 \%$ \\
\hline Other Social Science & $15 \%$ & $7 \%$ \\
\hline Natural Science & $16 \%$ & $5 \%$ \\
\hline Humanities & $13 \%$ & $15 \%$ \\
\hline Other & $18 \%$ & $23 \%$ \\
\hline More than one & $8 \%$ & $9 \%$ \\
\hline \multicolumn{3}{|l|}{ Year at University } \\
\hline First & $40 \%$ & $11 \%$ \\
\hline Second & $23 \%$ & $38 \%$ \\
\hline Third & $23 \%$ & $16 \%$ \\
\hline Fourth & $13 \%$ & $12 \%$ \\
\hline Fifth & $1 \%$ & $23 \%$ \\
\hline \multicolumn{3}{|l|}{ Law Experience } \\
\hline Yes & $25 \%$ & $40 \%$ \\
\hline No & $75 \%$ & $60 \%$ \\
\hline
\end{tabular}




\section{Study 2 results}

Responses to all of the vignette items were analyzed in a 4 (property domain: patent vs. copyright vs. personal property vs. real property) $\times 3$ (transfer type: private-for-private vs. private-forpublic vs. public-for-public) $\times 2$ (group: American vs. Chinese) mixed measures ANOVA with group as a between-subjects factor and domain and transfer type as within-subjects factors. All pairwise comparisons are Bonferroni corrected. ${ }^{157}$

As in Study 1, analyses revealed that there was a statistically significant effect of the property domain on participant responses. ${ }^{158}$ Participants believed that using someone else's personal property $(M=27.41, S D=28.50)$ should be less permissible than using someone else's intellectual property (patent: $M=38.22, S D=32.99$; copyright: $M=36.89, S D=41.05 ; p s<.001)$ or real property $(M=34.74, S D=31.43 ; p<.001)$. Responses for the two types of intellectual property and the real property cases did not differ from each other (all ps > .387).

Analyses again revealed a significant effect of transfer type on vignette evaluations as well. ${ }^{159}$ The study respondents believed that private-for-private uses of property $(M=21.73, S D=27.59)$ should be less allowed than private-for-public uses of property $(M=39.36$, $S D=32.73 ; p<.001)$, or public-for-public uses of property $(M=$ $41.85, S D=33.21 ; p<.001)$. Further, participants believed that private-for-public uses of property should be less allowed than public-for-public uses of property $(p=.014)$.

Contrary to Study 1, there was a significant effect of participants' race/ethnicity on their property scenario evaluations. ${ }^{160}$ American participants $(M=28.36, S D=26.23)$ were significantly more likely to say that the takings of property should not be allowed compared to Chinese participants $(M=40.27$, $S D=32.80)$.

157. The Bonferroni correction is a commonly used statistical tool applied when several statistical tests are performed simultaneously on a single data set. REBECCA M. WARNER, Applied Statistics: From Bivariate Through Multivariate Techniques 98 (2d ed. 2013); see D. James Greiner et al., The Limits of Unbundled Legal Assistance: A Randomized Study in a Massachusetts District Court and Prospects for the Future, 126 HARV. L. REV. 901, 985 n.253 (2013) (noting the commonality of the Bonferroni correction).

158. $F(3,603)=20.19, p<.001, \eta p 2=.09$.

159. $F(2,402)=143.24, p<.001, \eta p 2=.42$.

160. $F(1,201)=12.62, p<.001, \eta p 2=.06$. 
The effects of property domain and transfer type described above were qualified by a significant interaction between them. ${ }^{161}$ In each of the property domains, participants were more strict about the private-for-private transfers $(M=21.78, S D=27.62)$ compared to the private-for-public transfers $(M=39.38, S D=26.74)$ and the public-for-public transfers $(M=41.87, S D=26.47$; all $p \mathrm{~s}<$ $.001)$. However, while respondents were marginally more strict about the private-for-public transfers compared to the public-forpublic transfers in the copyright domain $(p=.059)$, they evaluated the private-for-public and public-for-public transfers similarly in the patent $(p=.175)$, personal property $(p=1.0)$, and real property $(p=1.0)$ domains. In addition, after plotting the results and seeing what appeared to be a difference across culture in the private-forprivate items, we explored whether Chinese and American participants differed in means for each type of transfer. ${ }^{162}$ We found that American participants $(M=11.17)$ were substantially more strict about private-for-private transfers than Chinese participants $(M=32.38),{ }^{163}$ and American participants $(M=35.47)$ were also significantly more strict about private-for-public transfers than Chinese participants $(M=43.26) .{ }^{164}$ In contrast, the difference between American $(M=38.45)$ and Chinese participants $(M=45.26)$ for public-for-public transfers was not significant ( $p=.067)$.

There was also a significant interaction between race/ethnicity and transfer type. ${ }^{165}$ This interaction revealed that both Chinese and Americans were more strict about the private-for-private transfers compared to the private-for-public transfers (all $p \mathrm{~s}<.001$ ), and the public-for-public transfers (all $p s<.001$ ). However, while the Chinese participants evaluated the private-for-public and publicfor-public scenarios as similar $(p=.311)$, in contrast to Study 1, American participants were more strict about the private-for-public compared to the public-for-public scenarios $(p=.049)$.

Unlike Study 1, there was a significant interaction between race/ethnicity and property domain. ${ }^{166}$ This relationship revealed that the main effect of property domain -that participants were

\footnotetext{
161. $F(6,1206)=3.88, p=.001, \eta p 2=.019$.

162. These results may be taken with caution because they are post hoc.

163. $t(201)=5.88, p<.001, d=.83$.

164. $t(201)=2.09, p=.038, d=.29$.

165. $F(2,402)=19.98, p<.001, \eta p 2=.09$.

166. $F(3,603)=7.21, p<.001, \eta p 2=.04$.
} 
more strict about the use of personal property than intellectual or real property-was stronger among American participants than among Chinese participants. American participants were significantly more likely to say taking property should not be allowed in the personal property domain compared to the intellectual property and land domains $(p s<.001)$. Further, the American participants were more strict about the land domain compared to the copyright domain $(p=.039)$; however, they were no more strict about land than about patent $(p=.140)$, and evaluated copyright and patent statistically similarly $(p=1.0)$. On the other hand, Chinese participants were only significantly more strict about the personal property domain compared to the patent domain $(p=.006)$. Aside from the aforementioned finding, and a marginally significant difference in participants' responses to the personal property and land domains $(p=.067)$, Chinese participants did not evaluate the four domains differentially (all $p$ s > .474).

Finally, these interactions were further qualified by a significant three-way interaction between race/ethnicity, transfer type, and property domain, suggesting some differences between cultures with respect to how domain and transfer type interact. ${ }^{167}$ The threeway interaction revealed that American and Chinese participants show a similar pattern in response to the three transfer types in the patent, personal property, and land domains, such that in all three domains participants were more strict about private-for-private transfers compared to private-for-public transfers (all $p \mathrm{~s}<.026$ ), and compared to public-for-public transfers (all ps < .002), but evaluated the private-for-public and public-for-public transfers similarly (all $p \mathrm{~s}>$.415). The pattern of responses from American and Chinese groups differed slightly for the copyright domain. In the copyright domain, both groups were stricter about private-forprivate transfers compared to private-for-public transfers ( $p s<$ $.001)$ and compared to public-for-public transfers $(p s<.001)$. However, while Americans were more strict about private-forpublic transfers relative to public-for-public transfers $(p=.024)$, Chinese participants evaluated these two scenarios similarly $(p=$ 1.0). The results of the Study 2 vignette evaluations are displayed in Figure 2.

167. $F(6,1206)=4.54, p<.001, \eta p 2=.02$. 
Figure 2. Study 2: Legal Permissibility Ratings of Vignettes by Transfer Type, Domain, and Group.

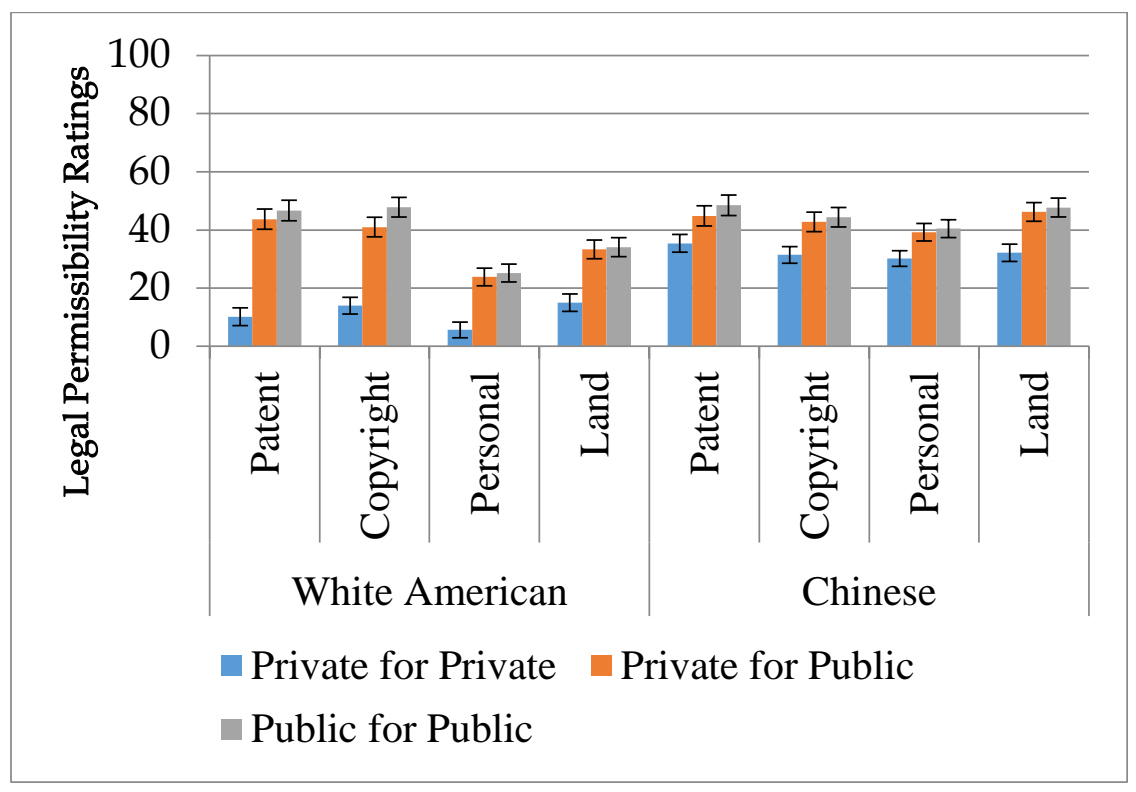

In contrast to the East Asian and White American groups in Study 1 who differed on the legal compliance questions, Chinese and American participants in Study 2 did not differ in their responses on the legal compliance questions. ${ }^{168}$ Both American ( $M$ $=82.14, S D=15.68)$ and Chinese $(M=78.22, S D=26.78)$ participant Compliance Support scores averaged significantly above the midpoint (50), indicating a desire for compliance with property and intellectual property law. ${ }^{169}$

On the self-construal scale, consistent with Study 1, the two groups differed significantly in their tendency to endorse independent self-construal, ${ }^{170}$ such that American participants reported higher independent self-construal $(M=4.75, S D=0.63)$ than Chinese participants $(M=4.06, S D=0.76)$. Unlike the groups in Study 1, the Study 2 groups also differed significantly in their tendency to endorse interdependent self-construal, ${ }^{171}$ such that

168. $t(201)=1.27, p=.204$.

169. American: $t(100)=20.59, p<.001$; Chinese: $t(101)=10.64, p<.001$.

170. $t(201)=6.98, p<.001, d=.99$.

171. $t(201)=7.40, p<.001, d=1.25$. 
American participants (somewhat counterintuitively) reported higher interdependent self-construal $(M=4.90, S D=0.54)$ than Chinese participants $(M=4.21, S D=0.78)$. The results of the studies are discussed in Part III.

\section{RECONCEPTUALIZING CUlTURE, PROPERTY, AND INTELLECTUAL PROPERTY EXCEPTIONALISM}

For decades, the common perception across much of the Western world has been that Chinese do not respect intellectual property rights. ${ }^{172}$ This critique is based on the perception that Chinese attitudes towards intellectual property rights are in some way exceptional, different from what they should be and different from other people's attitudes towards intellectual property rights. The results of our experiments indicate that these attributions may be accurate in some respects, but not in others. The results strongly suggest that both American and Chinese attitudes towards intellectual property rights are more complex than previously realized. Our studies also indicate that perhaps we should be exploring a different exceptionalism question: Why do Americans differentiate their preferences for intellectual property rights so starkly from their preferences for other property rights?

As with all experimental work, the conclusions we draw from our results are limited by the representativeness of the samples. Our participants were college students, drawn from a single campus in the United States and a single campus in China. These samples may not be representative of the cultures at large. It is possible that American and Chinese college students are more culturally aligned with each other than American and Chinese populations in general, due to sharing an age cohort, the globalization of information and some aspects of culture, or other factors. The discussion below assumes that the American and Chinese populations that we sampled are at least somewhat representative of American and Chinese populations at large.

\section{A. American Preferences for Stronger Property Rights Are Contextual}

The survey experiments provide varied results concerning whether Americans tend to prefer stronger property rights than

172. See supra Part I. 
Chinese. On the one hand, there was no statistically significant difference in American and Chinese responses to the general questions on whether it was important to comply with real property rights, personal property rights, and intellectual property rights. On the other hand, Americans indicated stronger property rights preferences in the vignette responses overall.

One possible explanation for these seemingly inconsistent outcomes is that the variation may result from differences in the issues that people from each culture default to conceptually when asked about property rights without context. When queried in the abstract about support for property rights, there is substantial consistency across the cultures. When subjects are asked about specific scenarios, however, their responses and the consistency across cultures is more nuanced.

In the vignettes, Americans tended to demonstrate a preference for stronger property rights than the Chinese. Chinese participants' permissibility ratings averaged higher than Americans' for each type of property and for each type of transfer. ${ }^{173}$ Examining the twelve vignettes individually, Chinese permissibility ratings significantly exceeded American permissibility ratings in eight of the vignettes and were statistically equivalent in the other four. ${ }^{174}$

The American preference for stronger property rights than those preferred by Chinese appeared across all private-for-private scenarios, though not all private-for-public or public-for-public scenarios. In the scenarios that involve taking property for public purposes (whether by a private or public entity), Americans and Chinese have more similar responses to each other. In these circumstances, American and Chinese preferences are statistically similar in both the patent and copyright conditions, while Americans prefer slightly stronger rights in the personal property and land scenarios. Americans do not prefer stronger property rights to Chinese overall-rather, American preferences for property rights in comparison to Chinese preferences are highly context dependent.

173. Although there were significant differences across cultural groups in Study 2, such differences were not found in Study 1 . These results may indicate that there is a selection effect among East Asians who choose to come to college in the United States. Such individuals may bear property rights attitudes that are more similar to American attitudes.

174. The four that are equivalent, as noted in the prior section, concern patent and copyright protection when the taking is for a public purpose. 


\section{B. Chinese Consistency, American Variation}

One overarching result across the twelve vignette scenarios is that Chinese tended to view property rights significantly more consistently than did Americans. This uniformity held across the type of property, the entity taking the property, and the use to which the property was being put. As one indicator of this difference in variance, average Chinese responses across the twelve scenarios varied by about fifty percent, while American responses varied tenfold. This Chinese consistency across property domains is also revealed in participants' responses to the general property rights legal compliance questions. Here, the Chinese responses across personal, real, and intellectual property displayed a higher correlation than the American responses.

The Chinese consistency likely derives, at least in part, from millennia of viewing all property as belonging to the Emperor, and all people as the Emperor's subjects. It may also have roots in the history of property redistribution in China. These perspectives of state ownership of all property would tend to remove distinctions between different types of property and between public versus private property rights.

The American variation in responses here is somewhat beguiling in two regards. First, when queried in the abstract about the importance of complying with both property rights in general and intellectual property rights in particular, Americans rate such importance relatively consistently across the different domains (as do Chinese). When queried about specific factual patterns, however, only Americans draw sharp distinctions.

Second, the distinctions that Americans draw across different types of property rights are largely inconsistent with the U.S. law. Although property laws concerning tangible personal goods, land, and intellectual property do not mirror each other precisely, in general, the law does not differentiate between the taking of intangible property versus tangible property or the taking of property (by a private party) for a publicly directed versus privately directed purpose. There appears to be a significant disconnect between American preferences for property law and the 
law on the books, ${ }^{175}$ a disconnect that is not limited to a distinction between tangible and intangible property.

In this context, it is worth noting that we did not find race/ethnicity differences in Study 1. There, White Americans, East Asian Americans, and East Asians all had statistically similar responses to each other on property rights. The divergence between Americans and Chinese respondents in Study 2, on the other hand, provides evidence that East Asian Americans and East Asians who choose to attend college in the United States are culturally more similar to Americans than are other Chinese, at least with respect to property rights.

\section{Chinese Intellectual Property Exceptionalism, or American?}

Our results suggest that those on all sides of the debates over the origins of Chinese attitudes towards intellectual property rights miss the mark in certain regards. Both those who argue that Chinese attitudes are based in Confucian history and those who disagree built their arguments by focusing on Chinese cultural and legal developments in contrast to Western notions. That is, all parties assumed some form of intellectual property exceptionalism in Chinese culture. The studies reported here indicate that this is not the case.

First, whatever the basis for Chinese attitudes towards intellectual property rights, these attitudes appear to track Chinese attitudes towards tangible property closely. Correlation does not prove causation, but one likely explanation for this relationship is that the basis for Chinese attitudes towards intellectual property is the same as the basis for their attitude towards all property. To the extent Chinese attitudes are exceptional, it is not their attitudes towards intellectual property that are exceptional, but their attitudes towards property in general.

Second, Chinese attitudes towards intellectual property bear a significant resemblance to American attitudes towards intellectual property in certain regards. In both the copyright and patent

175. Other research similarly has documented a disconnect between American beliefs about what intellectual property law should be and what the law actually is. Anne A. Fast, Kristina R. Olson \& Gregory N. Mandel, Intuitive Intellectual Property Law: A NationallyRepresentative Test of the Plagiarism Fallacy, 12(9) PLoS ONE e0184315 (2017); Gregory N. Mandel, The Public Perception of Intellectual Property, 66 FLA. L. REV. 261, 308 (2014); Plagiarism Fallacy, supra note 23, at 971 . 
protection scenarios, Americans and Chinese had statistically similar responses for both private and public takings so long as they are for public benefit. The Chinese and American responses in the personal and real property scenarios deviated to a greater extent than the intellectual property scenarios. Here, the Chinese preferred weaker property protection in each of the three transfer type contexts.

\section{Purpose Matters}

As noted above, Americans see a sharp distinction concerning the use to which taken property is put. Americans consider it significantly more acceptable for private or public parties to take property for a public purpose than it is to take property for a private purpose. This differentiation holds across all four types of property tested here. Chinese participants display some distinction concerning use as well, though not as sharp as Americans in any of the four property domains.

On the other hand, neither Chinese nor Americans tended to draw much of a distinction based on the user taking the property private or public. ${ }^{176}$ In other words, when the purpose of the taking is held constant (that is, for a public purpose), respondents in each domain did not distinguish between private versus public entities engaging in the taking. These preferences run contrary to the law. In both the United States and China, the legal consequences of taking property can depend on whether it is a private party or the government that is taking the property. ${ }^{177}$

Policymakers and scholars have long debated whether the objectives of property law should be utilitarian or deontological in nature. Utilitarians argue that property laws should be designed instrumentally, to provide incentives for private parties to put property to its highest social use. ${ }^{178}$ Some contend that efficiency

176. Chinese participants did not draw a significant distinction between the privatefor-public and public-for-public vignettes for any of the property types. Americans similarly did not draw a significant distinction for personal, real, or patent property, but did draw a distinction for copyright.

177. Jan G. Laitos \& Teresa Helms Abel, The Role of Causation When Determining the Proper Defendant in a Takings Lawsuit, 20 WM. \& MARY BILL RTS. J. 1181, 1182-83 (2012); Dennis Schmelzer, Takings for Granted: The Convergence and Non-Convergence of Property Law in the People's Republic of China and the United States, 19 DUKE J. COMP. \& INT'L L. 133, 138 (2008).

178. Richard A. POSNER, ECONOMIC ANALYSIS OF LAW 40 (9th ed. 2014); Abraham Bell \& Gideon Parchomovsky, A Theory of Property, 90 CORNELL L. REV. 531, 547 (2005). 
objectives are the reason that society developed property laws in the first instance, for example in an effort to resolve the tragedy of the commons. ${ }^{179}$ While utilitarian views of property are consequentialist, deontologists focus on people's moral entitlement to certain property rights. ${ }^{180}$ Most famously, for example, John Locke's labor theory of property rights posits that people are naturally entitled to the fruits of their efforts. ${ }^{181}$ Rather than taking an instrumentalist view of property law, deontological proponents contend that there is and should be a moral basis for property law. ${ }^{182}$

The results described above shed some light on how the public tends to view property rights. In addition to being contrary to the law, the American and Chinese distinctions in the study scenarios according to the use of the property in question, but not according to the user, are contrary to deontological conceptions of private property rights. ${ }^{183}$ If private individuals are morally entitled to their property interests, then the permissibility of a taking or infringement should not depend on the use to which the property is being put. ${ }^{184}$ Permissibility views that depend on the use to which the property is put are more consistent with a utilitarian perception of property rights. ${ }^{185}$ Across the personal, real, and intellectual property scenarios tested here, the instrumentalist outcomes of the use of property affected participant responses.

There was a significant public outcry in the United States following the Supreme Court's decision in Kelo v. City of New London, ${ }^{186}$ which upheld the City's exercise of their eminent domain

179. Garrett Hardin, The Tragedy of the Commons, 162 SCIENCE 1243 (1968); Demsetz, supra note 98 , at 356 .

180. Micah Elazar, "Public Use" and the Justification of Takings, 7 U. PA. J. CONST. L. 249, 253 (2004); Heidi M. Hurd, Justifiably Punishing the Justified, 90 MICH. L. ReV. 2203, 2210 (1992).

181. JoHn LOCKE, THE SECOND TREATISE OF GOVERNMENT 17 (Thomas P. Reardon ed., Liberal Arts Press 1952) (1690); see also RICHARD A. EPSTEIN, TAKINGS: PRIVATE PROPERTY AND THE POWER OF EMINENT DOMAIN 11-12 (1985).

182. G.W.F. Hegel, Philosophy OF Right 45, at 52 (S.W. Dyde trans., 1996) (1896); Margaret Jane Radin, Property and Personhood, 34 STAN. L. REV. 957 (1982); Merrill \& Smith, supra note 99 , at 1894 .

183. Elazar, supra note 180, at 253; Hurd, supra note 180, at 2210.

184. D. Benjamin Barros, Property and Freedom, 4 N.Y.U. J.L. \& LIBERTY 36, $40-41$ (2009); Merrill \& Smith, supra note 99, at 1882.

185. POSNER, supra note 178 , at 41 ; Merrill \& Smith, supra note 99 , at $1881-82$.

186. Kelo v. City of New London, 545 U.S. 469 (2005); see Janice Nadler \& Shari Seidman Diamond, Eminent Domain and the Psychology of Property Rights: Proposed Use, Subjective 
power in taking real property. ${ }^{187}$ The Court in Kelo focused on the public use to which the property would be put in upholding the government's action under the Takings Clause of the Constitution. ${ }^{188}$ This study suggests that the Court's focus on public use is consistent with public preferences for how property rights should be determined in general. The negative reaction to Kelo thus may have had more to do with whether the use in question was actually public - here, a governmental taking exercised by a private party for development purposes ${ }^{189}$-than whether it was inappropriate for the Court to focus on public use in takings cases. ${ }^{190}$ These results are consistent with an earlier property rights study in relation to Kelo, which found that Americans believed that a government taking of real property was more justified when the planned use had a more legitimate public purpose. ${ }^{191}$

\section{E. Preferencing Personal Property}

Another finding that stands out in the results is the participants' preference for protecting personal property rights. Both Americans and Chinese concluded that personal property rights should be protected more rigorously than other types of property rights. Strikingly, this preference for personal property rights over rights in land existed whether the land vignette involved merely trespass (Study 1) or the full taking of real property (Study 2).

American participants responded across the board that personal property rights should be protected to a greater extent

Attachment, and Taker Identity, 5 J. EMPIRICAL LEGAL STUD. 713 (2008); Timothy Sandefur, The "Backlash" So Far: Will Americans Get Meaningful Eminent Domain Reform?, 2006 MiCH. ST. L. REV. 709, 711 (2006) (discussing the moral outrage about the Kelo decision and how this backlash was inspiring statutory reforms in state legislatures); Ilya Somin, The Limits of Backlash: Assessing the Political Response to Kelo, 93 MiNN. L. REV. 2100, 2101 (2009) (reporting on a survey of public opinion about Kelo and concluding, "[t]he Supreme Court's decision in Kelo v. City of New London generated a massive backlash from across the political spectrum"). But see Abraham Bell \& Gideon Parchomovsky, The Uselessness of Public Use, 106 COLUM. L. Rev. 1412 (2006) (surveying the academic criticism of Kelo and arguing that they are ill-conceived and misguided).

187. Kelo, 545 U.S. at 469.

188. Id. at $488-89$.

189. Id. at $483-86$

190. See John Fee, Eminent Domain and the Sanctity of Home, 81 Notre DAME L. REV. 783 (2006) (arguing that the public use doctrine developed in Kelo does not adequately protect against the taking of residential property).

191. See generally Nadler \& Diamond, supra note 186. 
than other types of property rights. Chinese participants responded that personal property rights should be more protected than land or patents, and their ratings for personal property and copyright did not statistically differ.

The comparison between the personal property and copyright vignettes is particularly worthy of note. In the former, the individual at issue in the scenario takes fifty tangible copies of a textbook and sells them to college classmates. In the latter, the individual scans a copyrighted textbook and sells access to fifty college classmates. In each scenario the property owner incurs the same financial loss. Americans viewed these two scenarios starkly differently, while Chinese viewed them similarly.

In the context of Kelo, it is worth noting that the government's constitutional takings power applies equally to personal property ${ }^{192}$ and effectively to intellectual property as well. ${ }^{193}$ Given the preferences for personal property protection expressed by the study participants here, it is possible that the public outcry against takings would be even stronger in a personal property case than it was in Kelo. ${ }^{194}$

Professor Margaret Radin famously posited that some property is "personal," not in the traditional sense of "personal property," but in the sense that ownership and control over it is essential to individual personhood. ${ }^{195}$ This normative view of property law

192. Horne v. Dep't of Agric., 135 S. Ct. 2419, 2426 (2015); Steven J. Eagle, Property Rights After Horne, 10 N.Y.U. J.L. \& LIBERTY 669 (2016).

193. 28 U.S.C. $\S 1498$ (mandating that the government pay "reasonable and entire compensation" (a) "whenever an invention... covered by a patent... is used or manufactured by or for the United States" and (b) "whenever the copyright in any work protected under the copyright laws [is] infringed by the United States"); Thomas F. Cotter, Do Federal Uses of Intellectual Property Implicate the Fifth Amendment?, 50 FLA. L. REV. 529, 53132 (1998) (noting that "the Federal Tort Claims Act permits trademark owners to file claims against the United States for the violation of state trademark law" and that even though "no federal statute explicitly authorizes suits against the United States for violations of federal trademark law ...., if the federal government's dilution of a trademark can be characterized as a taking of private property for public use, the owner may be able to obtain compensation from the government under the Tucker Act").

194. Professor Stephanie Stern has argued that there is scant empirical support for the strong emphasis that legislators placed on the psychological primacy of residential property rights following Kelo. Stephanie M. Stern, Residential Protectionism and the Legal Mythology of Home, 107 MicH. L. REV. 1093 (2009). The results here do not speak significantly to the ownership of home but do provide empirical support for the value that people place on personal property.

195. Radin, supra note 182 , at $957-58$. 
suggests that certain property is integral to personal autonomy, liberty, and human flourishing, and that property rights should be protected in order to promote such goals. ${ }^{196}$ Other property, Radin argues, is "fungible"; it can be bought and sold without injury to personhood interests, and therefore should be entitled to lesser protection. ${ }^{197}$ The results here provide some support for Radin's personhood theory of property law. For even seemingly mundane property, such as textbooks, the study participants attached meaning to the ownership of the object in question.

\section{F. The Psychology of Property Rights}

With regard to self-construal, the results of these studies were mixed. Consistent with considerable past work, ${ }^{198}$ in Studies 1 and 2, White American participants endorsed independent selfconstrual more than East Asian students (Study 1) and Chinese students (Study 2), but did not differ from East Asian American students (Study 1). In contrast, we did not observe the expected difference on interdependent self-construal. In Study 1, the groups did not differ in their level of interdependence, and in Study 2, White Americans actually endorsed an interdependent selfconstrual more than Chinese participants. Whether the latter effect was a spurious finding, the result of translation difficulties (that somehow had not affected the independent measure), a product of the uniqueness associated with college student populations, or a reflection of a generational change since the scale was first constructed, ${ }^{199}$ is an open question. Nonetheless, these findings demonstrate that in making comparisons across countries, based on assumptions of cultural differences, it remains critical to continue to measure these cultural differences as it may not be fair to assume they remain constant across time or study.

We can also speculatively connect the vignette ratings to the self-construal findings. The disapproval of the private-for-private case was especially strong among Americans. Perhaps their higher rates of both independent self-construal and interdependent

196. Id. Contra Stephen J. Schnably, Property and Pragmatism: A Critique of Radin's Theory of Property and Personhood, 45 STAN. L. REV. 347, 350-52 (1993).

197. Radin, supra note 182 , at $978-79$.

198. Oyserman et al., supra note 119 , at 3-72.

199. Singelis, supra note 128 , at 580 . 
self-construal particularly impacted this case. In private-for-private transfers, the personal costs to the owner (which might be especially salient to someone with an independent self-construal) were not outweighed by a concern for the larger group (which might be salient to someone with an interdependent self-construal). The literature on self-construal has investigated how self-construal can influence cognition. For example, representations of the self can impact spatial judgments, ${ }^{200}$ attention to context, ${ }^{201}$ and engagement in situational versus dispositional attributions. ${ }^{202}$ The current findings add to this work by suggesting that self-construal may also be useful in thinking about third-party judgments.

Further, the current findings expand the psychology of ownership literature by demonstrating that people's intuitions about the acceptability of using another's property shift as a function of how (or for whom) that property is used. Previous research demonstrated that adults and even young children focus on current ownership when determining who has control over use of an object, even when a non-owner could more effectively use the object. ${ }^{203}$ However, when faced with dilemmas about an owner's property being used against the owner's will in order to prevent harm to others, adults and children as young as four years of age will deny the rights of owners in favor of the good deed. ${ }^{204}$ In the current work, we observed that whom the use benefited impacted the perceived acceptability of using the property. We found that people in both cultures viewed property used for the public similarly and more favorably than property used for private use, suggesting a common underlying utilitarian approach to evaluating these scenarios. That is, across cultures, helping more people was particularly important. This finding is consistent with

200. Aradhna Krishna et al., The Effect of Self-Construal on Spatial Judgments, 35 J. CONSUMER RES. 337, 337-48 (2008).

201. Richard S. Lewis et al., Culture and Context: East Asian American and European American Differences in P3 Event-Related Potentials and Self-Construal, 34 PERSONALITY \& SOC. PSYCH. BULL. 623, 623-34 (2008).

202. Morris \& Peng, supra note 12, at 949-71; Shigehiro Oishi et al., Cultural Variation in the Use of Current Life Satisfaction to Predict the Future, 78 J. PERSONALITY \& SOC. PSYCH. 434, 434-45 (2000).

203. Sunae Kim \& Charles W. Kalish, Children's Ascriptions of Property Rights with Changes of Ownership, 24 Cognitive Dev. 322, 322-36 (2009).

204. Karen R. Neary \& Ori Friedman, Young Children Give Priority to Ownership When Judging Who Should Use an Object, 85 CHILD DEV. 326, 326-37 (2013). 
other findings in moral psychology in which providing a benefit for greater numbers of people is generally favored. ${ }^{205}$

\section{CONCLUSION}

For years, legal and policy experts have debated and critiqued Chinese approaches to intellectual property rights. Despite a plethora of discussion on the matter, no one has previously tested actual American and Chinese property rights attitudes. The studies reported here present a first step forward. The results indicate that Americans and Chinese have richer and more complex preferences for property rights than previously considered, and that comparison of attitudes across cultures is not as straightforward as commonly assumed.

While Americans do tend to prefer stronger property rights, they do not do so in all situations, and their responses are significantly mediated by the context. Chinese are more consistent in their property rights views, though, like Americans, their preferences often do not align with actual law.

The variations across and complexities within each culture are likely intertwined with the historical and cultural differences across the two societies. While our results offer significant new information concerning American and Chinese preferences for property rights, they also only begin to scratch the surface. Both the United States and China have rich cultural diversity within their societies, which our studies did not explore. Beyond China and the United States there are many other countries whose differing histories and cultures likely yield alternative perspectives on property. The studies reported here open up many new avenues for research concerning property, intellectual property, and culture.

205. Judith Jarvis ThOMSON, Rights, Restitution, AND Risk: Essays IN MORAL THEORY (William Parent ed., 1986); Paul Conway \& Bertram Gawronski, Deontological and Utilitarian Inclinations in Moral Decision Making: A Process Dissociation Approach, $104 \mathrm{~J}$. PERSONALITY \& SOC. PSYCH. 216, 216-35 (2013); Joshua D. Greene et al., An fMRI Investigation of Emotional Engagement in Moral Judgment, 293 SCIENCE 2105, 2105-08 (2001). 